Article

\title{
Catalytic performance enhancement by alloying Pd with Pt on ordered mesoporous manganese oxide for methane combustion
}

\author{
Peng Xu, Zhixing Wu, Jiguang Deng, Yuxi Liu, Shaohua Xie, Guangsheng Guo*, Hongxing Dai \# \\ Beijing Key Laboratory for Green Catalysis and Separation, Key Laboratory of Beijing on Regional Air Pollution Control, Key Laboratory of Advanced \\ Functional Materials, Education Ministry of China, and Laboratory of Catalysis Chemistry and Nanoscience, Department of Chemistry and Chemical Engi- \\ neering, College of Environmental and Energy Engineering, Beijing University of Technology, Beijing 100124, China
}

\section{A R T I C L E I N F O}

\section{Article history:}

Received 31 August 2016

Accepted 25 September 2016

Published 5 January 2017

\section{Keywords:}

Ordered mesoporous manganese oxide Pd-Pt alloy nanoparticle

Supported noble metal catalyst

Strong metal-support interaction

Methane combustion

\begin{abstract}
A B S T R A C T
Ordered mesoporous $\mathrm{Mn}_{2} \mathrm{O}_{3}$ (meso- $\mathrm{Mn}_{2} \mathrm{O}_{3}$ ) and meso- $\mathrm{Mn}_{2} \mathrm{O}_{3}$-supported $\mathrm{Pd}, \mathrm{Pt}$, and Pd-Pt alloy $x\left(\mathrm{Pd}_{y} \mathrm{Pt}\right) / \mathrm{meso}_{-} \mathrm{Mn}_{2} \mathrm{O}_{3} ; x=(0.10-1.50) \mathrm{wt} \% ; \mathrm{Pd} / \mathrm{Pt}$ molar ratio $(y)=4.9-5.1$ nanocatalysts were prepared using KIT-6-templated and poly(vinyl alcohol)-protected reduction methods, respectively. The meso- $\mathrm{Mn}_{2} \mathrm{O}_{3}$ had a high surface area, i.e., $106 \mathrm{~m}^{2} / \mathrm{g}$, and a cubic crystal structure. Noble-metal nanoparticles (NPs) of size 2.1-2.8 nm were uniformly dispersed on the meso- $\mathrm{Mn}_{2} \mathrm{O}_{3}$ surfaces. Alloying Pd with Pt enhanced the catalytic activity in methane combustion; $1.41\left(\mathrm{Pd}{ }_{5.1} \mathrm{Pt}\right) / \mathrm{meso}^{-} \mathrm{Mn}_{2} \mathrm{O}_{3}$ gave the best performance; $T_{10 \%}, T_{50 \%}$, and $T_{90 \%}$ (the temperatures required for achieving methane conversions of $10 \%, 50 \%$, and $90 \%$ ) were 265,345 , and $425^{\circ} \mathrm{C}$, respectively, at a space velocity of $20000 \mathrm{~mL} /(\mathrm{g} \cdot \mathrm{h})$. The effects of $\mathrm{SO}_{2}, \mathrm{CO}_{2}, \mathrm{H}_{2} \mathrm{O}$, and $\mathrm{NO}$ on methane combustion over $1.41\left(\mathrm{Pd}_{5.1} \mathrm{Pt}\right) /$ meso- $\mathrm{Mn}_{2} \mathrm{O}_{3}$ were also examined. We conclude that the good catalytic performance of $1.41\left(\mathrm{Pd}_{5.1} \mathrm{Pt}\right) /$ meso- $\mathrm{Mn}_{2} \mathrm{O}_{3}$ is associated with its high-quality porous structure, high adsorbed oxygen species concentration, good low-temperature reducibility, and strong interactions between Pd-Pt alloy NPs and the meso- $\mathrm{Mn}_{2} \mathrm{O}_{3}$ support.
\end{abstract}

(C) 2016, Dalian Institute of Chemical Physics, Chinese Academy of Sciences. Published by Elsevier B.V. All rights reserved.

\section{Introduction}

Methane is widely considered to be the cleanest available hydrocarbon energy source for transportation and industrial applications [1]. Methane itself, however, is a greenhouse gas, with a global warming effect 21-23 times greater than that of $\mathrm{CO}_{2}$ [2], and more serious pollutants (e.g., CO, nitrogen oxides, and unburned hydrocarbons) are always detected in the outlets of methane flame combustion [3]. Catalytic combustion of methane has many advantages over conventional flame combus- tion, e.g., suppression of $\mathrm{NO}_{x}$ and $\mathrm{CO}$ and emissions and more efficient energy use. Pd-based catalysts are commonly used for methane combustion because of their excellent low-temperature catalytic activities [4,5]. PdO is believed to be an important activity-controlling factor in catalyzing the oxidation of hydrocarbons, and the reduction of $\mathrm{PdO}$ to metallic $\mathrm{Pd}^{0}$ at high temperatures decreases the catalytic activity [6,7]; for example, Hellman et al. [8] found that the PdO (101) facet was more reactive than metallic $\mathrm{Pd}^{0}$ in methane combustion. Pd-based catalysts, however, have some major drawbacks: (1)

\footnotetext{
* Corresponding author. Tel: +86-10-67396118; fax: +86-10-67391983; E-mail: guogs@bjut.edu.cn

\# Corresponding author. Tel: +86-10-67396118; fax: +86-10-67391983; E-mail: hxdai@bjut.edu.cn

This work was supported by the Ph.D. Program Foundation of Ministry of Education of China (20131103110002); the NNSF of China (21377008), National High Technology Research and Development Program (863 Program, 2015AA034603), Foundation on the Creative Research Team Construction Promotion Project of Beijing Municipal Institutions, and Scientific Research Base Construction-Science and Technology Creation Platform-National Materials Research Base Construction.

DOI: 10.1016/S1872-2067(16)62567-6 | http://www.sciencedirect.com/science/journal/18722067 | Chin. J. Catal., Vol. 38, No. 1, January 2017
} 
they often have poor stability in steady-state methane combustion processes $[9,10]$, and (2) their exposure to water or sulfur-containing compounds can significantly reduce the activity via formation of inactive $\mathrm{Pd}(\mathrm{OH})_{2}$ and stable palladium sulfate phases $[5,11,12]$. These problems can be overcome by adding a second metal to generate a bimetallic alloy catalyst. Pt-based catalysts are also good catalysts for the combustion of hydrocarbons. The addition of Pt can increase the low-temperature methane combustion activity or hinder the growth of Pd or PdO particles [13]. Doping of a supported Pd catalyst with a small amount of Pt improves the thermal stability $[14,15]$ and enhances resistance to sulfur or water-vapor poisoning [12].

Transition-metal oxides (e.g., Mn [16,17], Co [18], $\mathrm{Cu}, \mathrm{Cr}$, and $\mathrm{Ni}$ [19]) have also been used as catalysts in methane combustion; they are cheaper, more stable at high temperatures [11], and more resistant to sulfur poisoning [19] than supported noble-metal catalysts. Among the transition-metal oxide catalysts developed so far, manganese oxides have been widely studied as possible alternative catalysts for methane combustion because of their varied and multiple oxidation states and oxygen-storage capacities [20]. Han's group [17] reported complete conversion of methane over $\alpha-\mathrm{Mn}_{2} \mathrm{O}_{3}$ at ca. $600{ }^{\circ} \mathrm{C}$, and this catalyst has ultrahigh stability. Machocki and coworkers [21] found that Ag-loaded manganese-lanthanum oxides showed good catalytic activities in methane combustion, and the reaction rate was related to the surface $\mathrm{Mn}^{4+} / \mathrm{Mn}^{3+}$ molar ratio.

Recently, our group investigated a number of nanosized or porous catalysts (e.g., Au-Pd/meso- $\mathrm{Co}_{3} \mathrm{O}_{4}$ [22], $\mathrm{Au}-\mathrm{Pd} / 3 \mathrm{DOM}$ $\mathrm{Co}_{3} \mathrm{O}_{4}$ [23], $\mathrm{Au}-\mathrm{Pd} / 3 \mathrm{DOM} \mathrm{Mn}_{2} \mathrm{O}_{3}$ [24], $\mathrm{Au} / 3 \mathrm{DOM} \mathrm{Mn}_{2} \mathrm{O}_{3}$ [25], $\mathrm{Au} / \mathrm{meso}-\mathrm{Mn}_{2} \mathrm{O}_{3}$ [26], Au-Pd/meso- $\mathrm{Cr}_{2} \mathrm{O}_{3}$ [27], and $\mathrm{Ag} / \mathrm{Mn}_{2} \mathrm{O}_{3}$ nanowires [28]), and found that most of them (especially the bimetallic catalysts) performed well in the oxidation of typical volatile organic compounds and/or CO. We introduced a small amount of Pt to generate Pd-Pt alloy nanoparticles (NPs) and loaded them via a poly(vinyl alcohol) (PVA)-protected reduction route on KIT-6-derived ordered mesoporous $\mathrm{Mn}_{2} \mathrm{O}_{3}$ (meso- $\mathrm{Mn}_{2} \mathrm{O}_{3}$ ) with specific redox properties to overcome the drawbacks of Pd-based catalysts. We investigated their physicochemical properties and evaluated their catalytic performances in methane combustion. Ordered meso- $\mathrm{Mn}_{2} \mathrm{O}_{3}$ has a good-quality porous structure and a high surface area, therefore its use as a support for metal alloy catalysts with a uniform particle distribution improves the catalytic activity and stability. To the best of our knowledge, there have been no reports of the preparation of three-dimensional ordered meso- $\mathrm{Mn}_{2} \mathrm{O}_{3}$-supported metal alloy catalysts and their use as methane combustion catalysts.

\section{Experimental}

\subsection{Catalyst preparation}

Mesoporous silica (KIT-6) and ordered meso- $\mathrm{Mn}_{2} \mathrm{O}_{3}$ were synthesized using previously reported procedures [29,30]. In a typical synthesis, KIT-6 (1.0 g) was suspended in toluene (50 $\mathrm{mL}$ ). The mixture was stirred at $65^{\circ} \mathrm{C}$ for $0.5 \mathrm{~h}$ and $\mathrm{Mn}\left(\mathrm{NO}_{3}\right)_{2}$ aqueous solution (50 wt $\%, 20.00 \mathrm{mmol}$ ) was added under vigorous stirring. The mixture was stirred at $65^{\circ} \mathrm{C}$ for $3 \mathrm{~h}$. A powder was obtained by filtration and drying the residue at room temperature (rt). The precursor@silica composite was placed in a crucible and calcined in a muffle furnace from $\mathrm{rt}$ to $600{ }^{\circ} \mathrm{C}$ at a ramping rate of $1{ }^{\circ} \mathrm{C} / \mathrm{min}$; this temperature was maintained for $6 \mathrm{~h}$. The silica template was removed by etching twice with hot $\mathrm{NaOH}$ aqueous solution $(2.00 \mathrm{~mol} / \mathrm{L})$. Template-free meso- $\mathrm{Mn}_{2} \mathrm{O}_{3}$ was obtained by centrifugation, washing with deionized water and ethanol, and drying at $80^{\circ} \mathrm{C}$.

Ordered meso- $\mathrm{Mn}_{2} \mathrm{O}_{3}$-supported Pd-Pt alloy catalysts were prepared via a PVA $\left(\mathrm{MW}_{\text {aver. }}=10000 \mathrm{~g} / \mathrm{mol}\right)$-protected reduction route with $\mathrm{NaBH}_{4}$ as a reducing agent [31]. The typical preparation procedure was as follows. A desired amount of PVA was added to an aqueous solution of $\mathrm{PdCl}_{2}$ and $\mathrm{H}_{2} \mathrm{PtCl}_{4}$ $(100 \mathrm{mg} / \mathrm{L}, \mathrm{Pd} / \mathrm{Pt}$ molar ratio $=5.0)$ in an ice bath; the mixture was stirred vigorously for $20 \mathrm{~min}$. A certain amount of $\mathrm{NaBH}_{4}$ aqueous solution $(0.1 \mathrm{~mol} / \mathrm{L})$ was quickly added to the mixed solution, generating a dark-brown noble-metal sol. A desired amount of meso- $\mathrm{Mn}_{2} \mathrm{O}_{3}$ powder was added to the noble-metal sol (theoretical Pd-Pt loadings $=(0.1,1.0$, and 1.5) wt\%) and the mixture was stirred for $6 \mathrm{~h}$. The mixture was filtered, washed with deionized water, and dried at $80^{\circ} \mathrm{C}$ for $12 \mathrm{~h}$. The dried powders were calcined in a muffle furnace from rt to 600 ${ }^{\circ} \mathrm{C}$, at a ramping rate of $1{ }^{\circ} \mathrm{C} / \mathrm{min}$, and then this temperature was maintained for $6 \mathrm{~h} ; x(\mathrm{Pd} y \mathrm{Pt}) /$ meso- $\mathrm{Mn}_{2} \mathrm{O}_{3}$ samples were obtained. Inductively coupled plasma atomic emission spectroscopy (ICP-AES) showed that the actual loadings $(x)$ of the noble metals were $(0.07,0.72$, and 1.41$) w t \%$, respectively, and the corresponding $y$ values were $4.9,5.1$, and 5.1 .

For comparison, $x \mathrm{Pd} /$ meso- $\mathrm{Mn}_{2} \mathrm{O}_{3}, x \mathrm{Pt} /$ meso- $\mathrm{Mn}_{2} \mathrm{O}_{3}$, and $x\left(\mathrm{Pd}_{y} \mathrm{Pt}\right) /$ bulk- $\mathrm{Mn}_{2} \mathrm{O}_{3}$ samples were also prepared using the same method. ICP-AES showed that the actual Pd, Pt, and Pd-Pt loadings $(x)$ were $(1.40,1.42$, and 0.70$) \quad w t \%$ in $x \mathrm{Pd} /$ meso- $\mathrm{Mn}_{2} \mathrm{O}_{3}, x \mathrm{Pt} /$ meso- $\mathrm{Mn}_{2} \mathrm{O}_{3}$, and $x\left(\mathrm{Pd}_{y} \mathrm{Pt}\right) /$ bulk- $\mathrm{Mn}_{2} \mathrm{O}_{3}$, respectively; the actual $\mathrm{Pd} / \mathrm{Pt}$ molar ratio $(y)$ in $x\left(\mathrm{Pd}_{y} \mathrm{Pt}\right) /$ bulk- $\mathrm{Mn}_{2} \mathrm{O}_{3}$ was 4.9 .

\subsection{Catalyst characterization}

X-ray diffraction (XRD) patterns of the samples were recorded using a Bruker D8 Advance diffractometer with $\mathrm{Cu} \mathrm{K \alpha}$ radiation and a Ni filter $(\lambda=0.15406 \mathrm{~nm})$. Elemental analyses of the noble-metal loadings were performed using ICP-AES (Thermo Electron IRIS Intrepid ER/S spectrometer). Transmission electron microscopy (TEM) and selected-area electron diffraction (SAED) were performed using a JEOL-2010 instrument operated at $200 \mathrm{kV}$. High-angle annular dark-field and scanning transmission electron microscopy (HAADF-STEM) were used to acquire HAADF and element mapping images (FEI G2 80-200/Chemi-STEM Cs-corrected transmission electron microscope with probe corrector). The Brunauer-Emmett-Teller (BET) surface areas of the samples were determined based on $\mathrm{N}_{2}$ adsorption at $-196{ }^{\circ} \mathrm{C}$ (Micromeritics ASAP 2020 analyzer); the samples were outgassed at $250^{\circ} \mathrm{C}$ for $2.5 \mathrm{~h}$ under vacuum before the measurements. Their pore-size distributions were calculated based on the desorption branches 
of the isotherms. X-ray photoelectron spectroscopy (XPS; VG CLAM 4 MCD analyzer) was used to determine the Mn $2 p, 01 s$, $\mathrm{Pd} 3 d$, Pt $4 f$, and $\mathrm{C} 1 s$ binding energies (BEs) of surface species, using $\mathrm{Mg} \mathrm{K \alpha}(h v=1253.6 \mathrm{eV})$ as the excitation source.

Temperature-programmed $\mathrm{H}_{2}$ reduction $\left(\mathrm{H}_{2}\right.$-TPR) experiments were performed using a chemical adsorption analyzer (Autochem II 2920, Micromeritics). Before the TPR measurements, the catalyst (40-60 mesh, ca. 0.050 g) was loaded into a quartz fixed-bed U-shaped microreactor (i.d. $=4 \mathrm{~mm}$ ) and pretreated in $\mathrm{O}_{2}$ flow $(20 \mathrm{~mL} / \mathrm{min})$ at $250^{\circ} \mathrm{C}$ for $1 \mathrm{~h}$. After cooling to $\mathrm{rt}$ in the same atmosphere, the system was purged with $\mathrm{He}$ flow ( $30 \mathrm{~mL} / \mathrm{min}$ ) for $15 \mathrm{~min}$. The pretreated sample was exposed to a flow (50 mL/min) of $5 \% \mathrm{H}_{2}-95 \% \mathrm{Ar}$ and heated from rt to $900{ }^{\circ} \mathrm{C}$ at a ramping rate of $10{ }^{\circ} \mathrm{C} / \mathrm{min}$. Changes in the $\mathrm{H}_{2}$ concentration in the effluent were monitored online using the chemical adsorption analyzer. The reduction peak was calibrated against that for complete reduction of a known standard, i.e., powdered $\mathrm{CuO}$ (Aldrich, 99.995\%).

The Fourier-transform infrared (FT-IR) spectrum of 1.41 $\left(\mathrm{Pd}_{5.1} \mathrm{Pt}\right) /$ meso- $\mathrm{Mn}_{2} \mathrm{O}_{3}$ ( $1 \mathrm{wt} \%$ sample $+99 \mathrm{wt} \% \mathrm{KBr}$ ) was recorded in the range $400-4000 \mathrm{~cm}^{-1}$ at a resolution of $4 \mathrm{~cm}^{-1}$ (Bruker Vertex 70 spectrometer). Before the spectrum was recorded, the sample was activated in $\mathrm{O}_{2}$ and methane, with the introduction of $100 \mathrm{ppm} \mathrm{SO}_{2}, 5.0 \mathrm{vol} \% \mathrm{CO}_{2}, 3.0 \mathrm{vol} \% \mathrm{H}_{2} \mathrm{O}$, and 1.0 vol\% NO.

\subsection{Catalytic evaluation}

The catalytic activities of the samples were evaluated using a continuous-flow fixed-bed quartz tubular microreactor (i.d. = $6.0 \mathrm{~mm}$ ). The sample (40-60 mesh, $50 \mathrm{mg}$ ) was diluted with quartz sand (40-60 mesh, $0.25 \mathrm{~g}$ ) to minimize the effects of hot spots. Before the test, each sample was treated in $\mathrm{O}_{2}$ flow (20 $\mathrm{mL} / \mathrm{min}$ ) at $250{ }^{\circ} \mathrm{C}$ for $1 \mathrm{~h}$. The reactant mixture consisted of 2.5 vol\% $\mathrm{CH}_{4}+20$ vol\% $\mathrm{O}_{2}+77.5$ vol $\% \mathrm{~N}_{2}$ (balance), and the total flow was $16.6 \mathrm{~mL} / \mathrm{min}$, giving a $\mathrm{CH}_{4} / \mathrm{O}_{2}$ molar ratio of $1 / 8$ and a space velocity (SV) of ca. $20000 \mathrm{~mL} /(\mathrm{g} \cdot \mathrm{h})$. A mass flow controller was used to introduce $100 \mathrm{ppm} \mathrm{SO}_{2}, 5.0$ vol\% $\mathrm{CO}_{2}$, and $1.0 \mathrm{vol} \% \mathrm{NO}$ from the corresponding $\mathrm{SO}_{2}, \mathrm{CO}_{2}$, and NO cylinders (balanced with $\mathrm{N}_{2}$ ) into the reaction system. Water vapor (3.0 vol\% $\mathrm{H}_{2} \mathrm{O}$ ) was introduced by passing the feed stream through a water saturator at a certain temperature. The reactants and products were analyzed online using a gas chromatograph (GC-14C, Shimadzu) equipped with a flame ionization detector and a thermal conductivity detector; a Stabilwax column (length $30 \mathrm{~m}$ ) was used for methane separation and a Carboxen 1000 column (length $3 \mathrm{~m}$ ) was used for permanent gas detection. The balance of carbon throughout the catalytic system was estimated to be $99.5 \%$. The catalytic activities of the samples were evaluated based on the temperatures $\left(T_{10 \%}\right.$, $T_{50 \%}$, and $T_{90 \%}$ ) required for achieving methane conversions of $10 \%, 50 \%$, and $90 \%$. The methane conversion was defined as $\left(c_{\text {inlet }}-c_{\text {outlet }}\right) / c_{\text {inlet }} \times 100 \%$, where $c_{\text {inlet }}$ and $c_{\text {outlet }}$ are the methane concentrations in the inlet and outlet feed streams, respectively.

\section{Results and discussion}

\subsection{Crystal phase composition, morphology, surface area, and particle size distribution}

Fig. 1 shows the XRD patterns of the prepared samples. A comparison with the XRD pattern of a standard $\mathrm{Mn}_{2} \mathrm{O}_{3}$ sample (JCPDS PDF\# 41-1442) shows that all the Bragg diffraction peaks (Fig. 1(a)) of the meso- $\mathrm{Mn}_{2} \mathrm{O}_{3}$ and $x(\mathrm{Pd} y \mathrm{Pt}) /$ meso- $\mathrm{Mn}_{2} \mathrm{O}_{3}$ samples can be indexed to a cubic crystal structure.

The sizes of the $\mathrm{Mn}_{2} \mathrm{O}_{3}$ (Table 1) crystallites in meso- $\mathrm{Mn}_{2} \mathrm{O}_{3}$ and the supported noble-metal samples, calculated using the Scherrer equation, were in the range 19.1-20.3 nm, whereas that of $\mathrm{Mn}_{2} \mathrm{O}_{3}$ in $0.07\left(\mathrm{Pd}{ }_{4} \mathrm{Pt}\right) /$ bulk- $\mathrm{Mn}_{2} \mathrm{O}_{3}$ was $70.7 \mathrm{~nm}$. No diffraction signals from noble-metal phases were detected because of the low loadings of noble metals and their good dispersion. The diffraction peak at $2 \theta=$ ca. $1^{\circ}$ in the small-angle XRD pattern (Fig. 1(b)) of meso- $\mathrm{Mn}_{2} \mathrm{O}_{3}$ and the supported no-

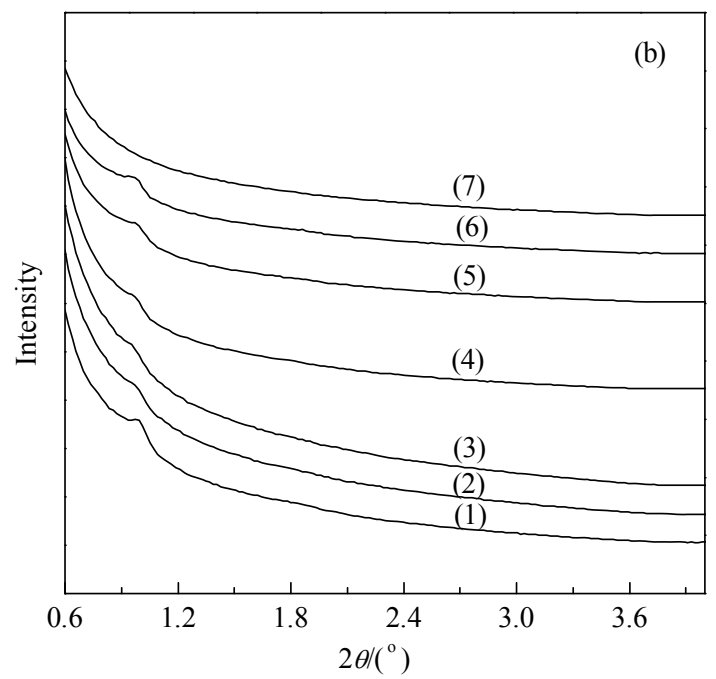

Fig. 1. (a) Wide-angle and (b) small-angle XRD patterns of (1) meso- $\mathrm{Mn}_{2} \mathrm{O}_{3}$, (2) $0.07\left(\mathrm{Pd} \mathrm{d}_{4.9} \mathrm{Pt}\right) / \mathrm{meso}-\mathrm{Mn}_{2} \mathrm{O}_{3}$, (3) $0.72\left(\mathrm{Pd}_{5.1} \mathrm{Pt}\right) / \mathrm{meso}-\mathrm{Mn}_{2} \mathrm{O}_{3}$, (4)

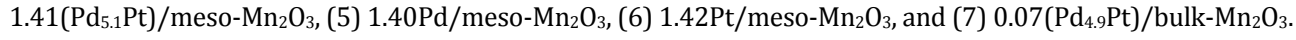


Table 1

BET surface areas, pore volumes, average pore sizes, $\mathrm{Mn}_{2} \mathrm{O}_{3}$ crystallite sizes $\left(D_{\mathrm{Mn} 203}\right)$, noble-metal particle sizes, real Pd or Pt contents, and real $\mathrm{Pd} / \mathrm{Pt}$ molar ratios of samples.

\begin{tabular}{|c|c|c|c|c|c|c|c|}
\hline Sample & $\begin{array}{c}\text { Surface area } \\
\left(\mathrm{m}^{2} / \mathrm{g}\right)\end{array}$ & $\begin{array}{l}\text { Pore volume } \\
\left(\mathrm{cm}^{3} / \mathrm{g}\right)\end{array}$ & $\begin{array}{l}\text { Average pore } \\
\text { size }(\mathrm{nm})\end{array}$ & $\begin{array}{c}D_{\mathrm{Mn} 203^{a}} \\
(\mathrm{~nm})\end{array}$ & $\begin{array}{c}\text { Nobel metal } \\
\text { particle size }{ }^{\mathrm{b}}\end{array}$ & 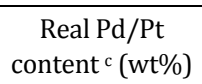 & $\begin{array}{c}\text { Real Pd/Pt } \\
\text { molar ratio }{ }^{c}\end{array}$ \\
\hline meso- $\mathrm{Mn}_{2} \mathrm{O}_{3}$ & 105.6 & 0.37 & 11.2 & 19.5 & - & $-1-$ & - \\
\hline $0.07\left(\mathrm{Pd}_{4.9} \mathrm{Pt}\right) /$ meso- $\mathrm{Mn}_{2} \mathrm{O}_{3}$ & 95.3 & 0.40 & 12.6 & 19.6 & - & $0.051 / 0.019$ & 4.9 \\
\hline $0.72\left(\mathrm{Pd}_{5.1} \mathrm{Pt}\right) /$ meso- $\mathrm{Mn}_{2} \mathrm{O}_{3}$ & 76.5 & 0.38 & 9.6 & 19.1 & 2.4 & $0.53 / 0.19$ & 5.1 \\
\hline 1.41 $\left(\mathrm{Pd}_{5.1} \mathrm{Pt}\right) /$ meso- $\mathrm{Mn}_{2} \mathrm{O}_{3}$ & 85.1 & 0.36 & 9.6 & 19.4 & 2.2 & $1.04 / 0.37$ & 5.1 \\
\hline 1.40Pd/meso- $\mathrm{Mn}_{2} \mathrm{O}_{3}$ & 89.9 & 0.35 & 9.3 & 20.2 & 2.8 & $1.40 /-$ & - \\
\hline $1.42 \mathrm{Pt} / \mathrm{meso}-\mathrm{Mn}_{2} \mathrm{O}_{3}$ & 83.5 & 0.35 & 9.9 & 20.3 & 2.5 & $-/ 1.42$ & - \\
\hline $0.07\left(\mathrm{Pd}_{4.9} \mathrm{Pt}\right) /$ bulk- $\mathrm{Mn}_{2} \mathrm{O}_{3}$ & 4.5 & 0.03 & - & 70.7 & 2.1 & $0.051 / 0.019$ & 4.9 \\
\hline
\end{tabular}

a Data were calculated according to the Scherrer equation using the FWHM of the (222) line of $\mathrm{Mn}_{2} \mathrm{O}_{3}$;

${ }^{b}$ Data were estimated according to the TEM images;

${ }^{c}$ Data were determined by the ICP-AES technique.

ble-metal samples indicates formation of an ordered mesoporous structure, but no small-angle XRD peaks were detected in $0.07\left(\mathrm{Pd}_{4.9} \mathrm{Pt}\right) /$ bulk- $\mathrm{Mn}_{2} \mathrm{O}_{3}$.
Fig. 2 shows the TEM images and SAED patterns of the samples. The meso- $\mathrm{Mn}_{2} \mathrm{O}_{3}$ and supported noble-metal samples had high-quality ordered mesoporous structures with a pore size of

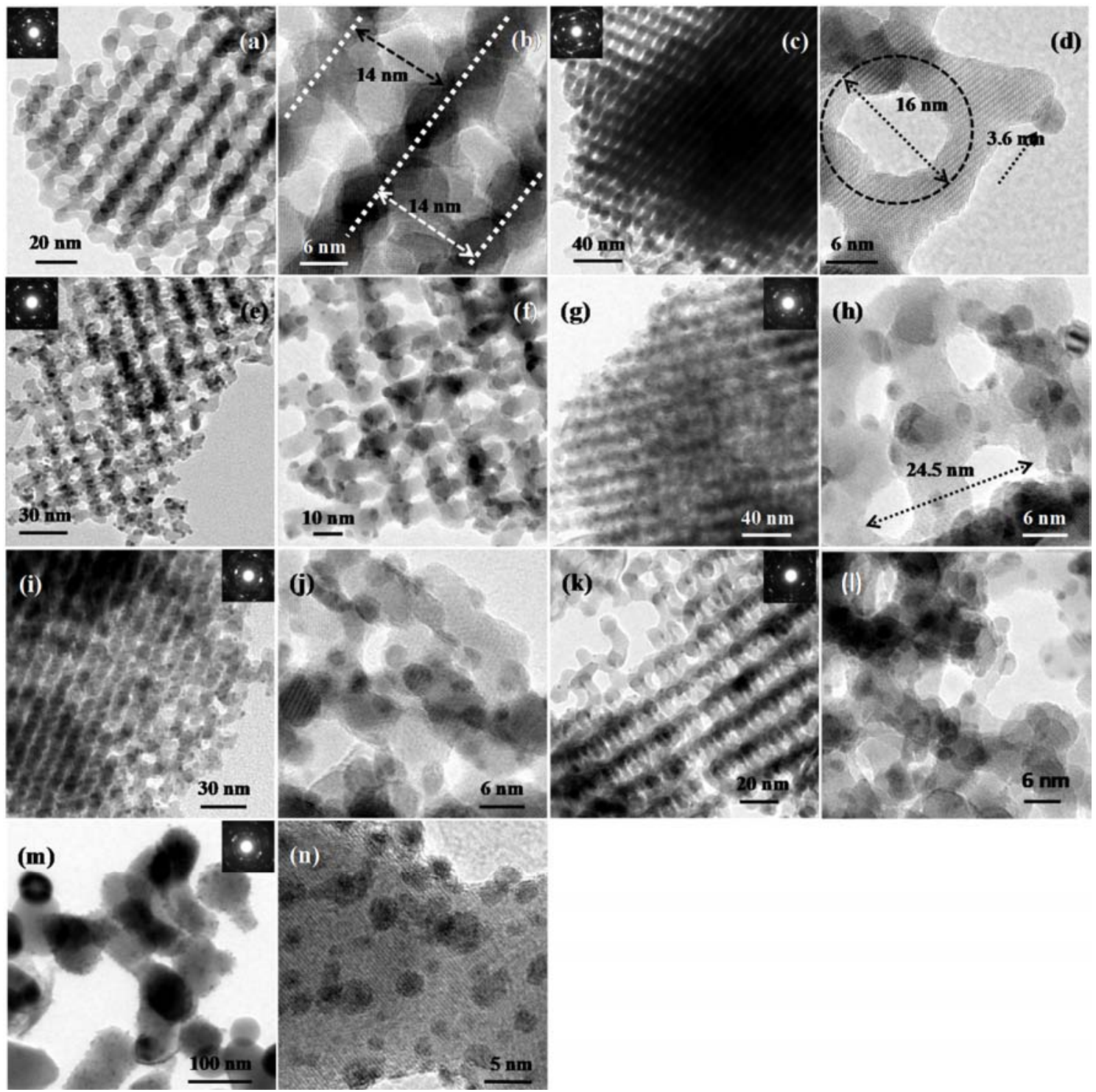

Fig. 2. TEM images and SAED patterns (insets) of (a, b) meso- $\mathrm{Mn}_{2} \mathrm{O}_{3}$, (c, d) $0.07\left(\mathrm{Pd}_{4.9} \mathrm{Pt}\right) / \mathrm{meso}^{-} \mathrm{Mn}_{2} \mathrm{O}_{3}$, (e, f) $0.72\left(\mathrm{Pd}_{5.1} \mathrm{Pt}\right) / \mathrm{meso}-\mathrm{Mn} \mathrm{O}_{3}$, (g, h) $1.41\left(\mathrm{Pd}_{5.1} \mathrm{Pt}\right) /$ meso- $\mathrm{Mn}_{2} \mathrm{O}_{3}$, (i, j) 1.40Pd/meso- $\mathrm{Mn}_{2} \mathrm{O}_{3}$, (k, l) 1.42Pt/meso- $\mathrm{Mn}_{2} \mathrm{O}_{3}$, and (m, n) 0.07( $\mathrm{Pd} \mathrm{d}_{4 .} \mathrm{Pt}$ )/bulk- $\mathrm{Mn}_{2} \mathrm{O}_{3}$. 
ca. $14 \mathrm{~nm}$ (Fig. 2(b) and (d)). Noble-metal NPs were highly dispersed on the $\mathrm{Mn}_{2} \mathrm{O}_{3}$ surfaces. The particle sizes of more than 70 noble-metal NPs in the supported samples were measured; the results are shown in Table 1 and Fig. 3. The average sizes of the noble-metal NPs in the supported samples were in the range $2.2-2.8 \mathrm{~nm}$. The multiple bright electron diffraction rings in the SAED patterns (Fig. 2(a), (c), (e), (g), (i), (k), and (m)) of the samples indicate that these materials were polycrystalline.

Fig. 4 shows the HAADF-STEM and element mapping images of $1.41\left(\mathrm{Pd}_{5.1} \mathrm{Pt}\right) /$ meso- $\mathrm{Mn}_{2} \mathrm{O}_{3}$. The figure clearly shows that a Pd-Pt alloy was formed using the PVA-protected reduction strategy with $\mathrm{NaBH}_{4}$ as the reducing agent.

Fig. 5 shows the $\mathrm{N}_{2}$ adsorption-desorption isotherms and pore-size distributions of the samples. The meso- $\mathrm{Mn}_{2} \mathrm{O}_{3}$ and supported noble-metal samples had type IV isotherms with a hysteresis loop in the relative pressure range 0.5-1.0 (Fig. $5(a)$ ), indicating generation of a mesoporous structure in these samples. The pore-size distribution curves (Fig. 5(b)) had two peaks, in the ranges $2-6$ and $10-16 \mathrm{~nm}$, respectively.

The BET surface areas and pore volumes of meso- $\mathrm{Mn}_{2} \mathrm{O}_{3}$ and the supported noble-metal samples were in the ranges $76.5-105.6 \mathrm{~m}^{2} / \mathrm{g}$ and $0.35-0.40 \mathrm{~cm}^{3} / \mathrm{g}$, respectively, much higher than those $\left(4.52 \mathrm{~m}^{2} / \mathrm{g}\right.$ and $\left.0.03 \mathrm{~cm}^{3} / \mathrm{g}\right)$ of $0.70\left(\mathrm{Pd}_{4.9} \mathrm{Pt}\right) /$ bulk- $\mathrm{Mn}_{2} \mathrm{O}_{3} \quad$ (Table 1). The meso- $\mathrm{Mn}_{2} \mathrm{O}_{3}$-supported noble-metal catalysts were prepared using the incipient wetness impregnation method, followed by

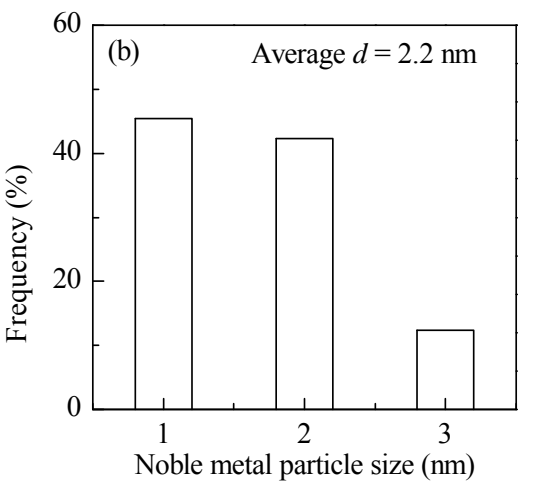

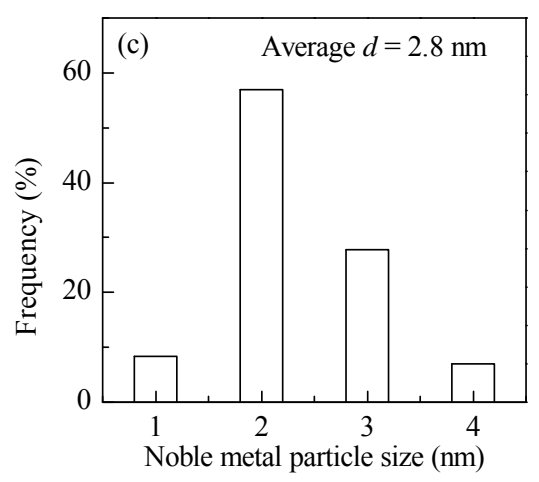
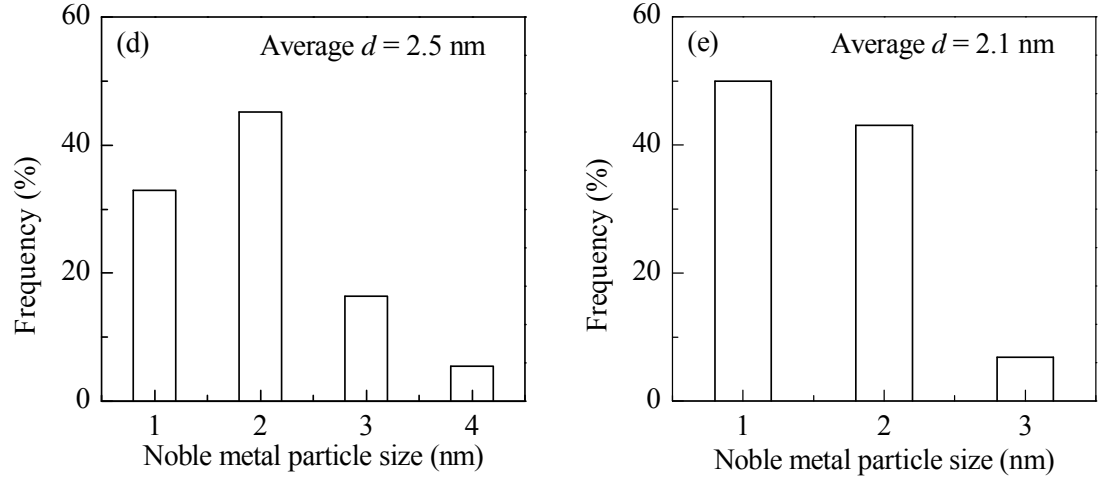

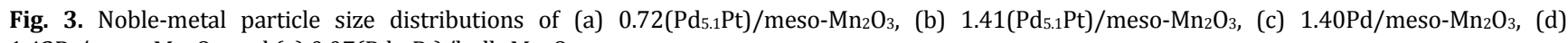
$1.42 \mathrm{Pt} /$ meso- $\mathrm{Mn}_{2} \mathrm{O}_{3}$, and (e) $0.07\left(\mathrm{Pd}_{4.9} \mathrm{Pt}\right) /$ bulk- $-\mathrm{Mn}_{2} \mathrm{O}_{3}$.
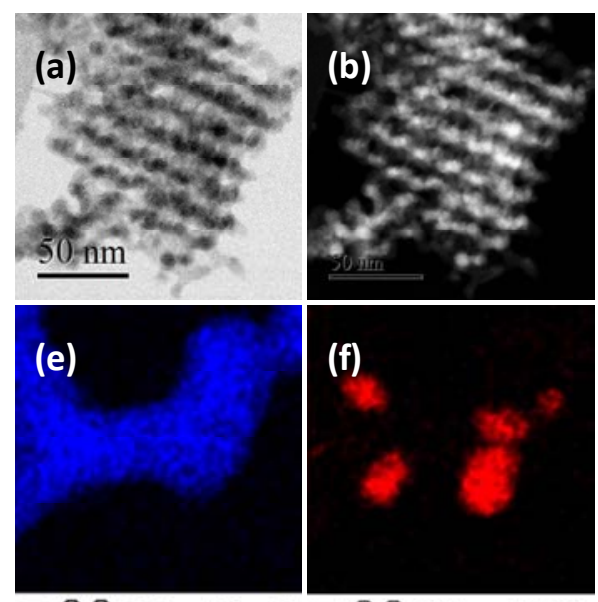

Pd L

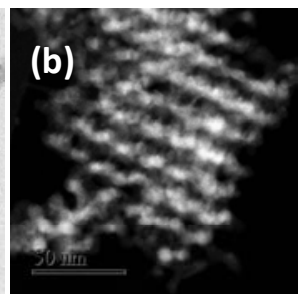

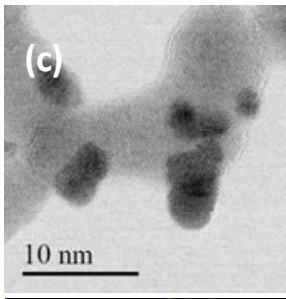
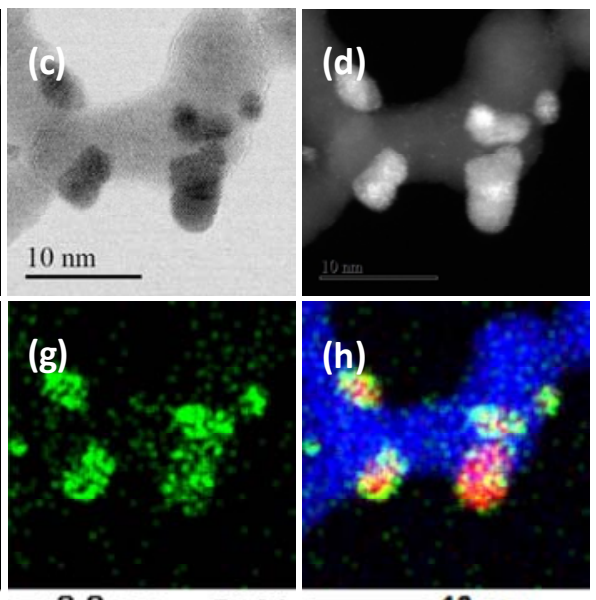

Fig. 4. (a-d) HAADF-STEM images and (e-h) element mapping images of $1.41\left(\mathrm{Pd} \mathrm{d}_{5.1} \mathrm{Pt}\right) / \mathrm{meso}^{-} \mathrm{Mn}_{2} \mathrm{O}_{3}$. 

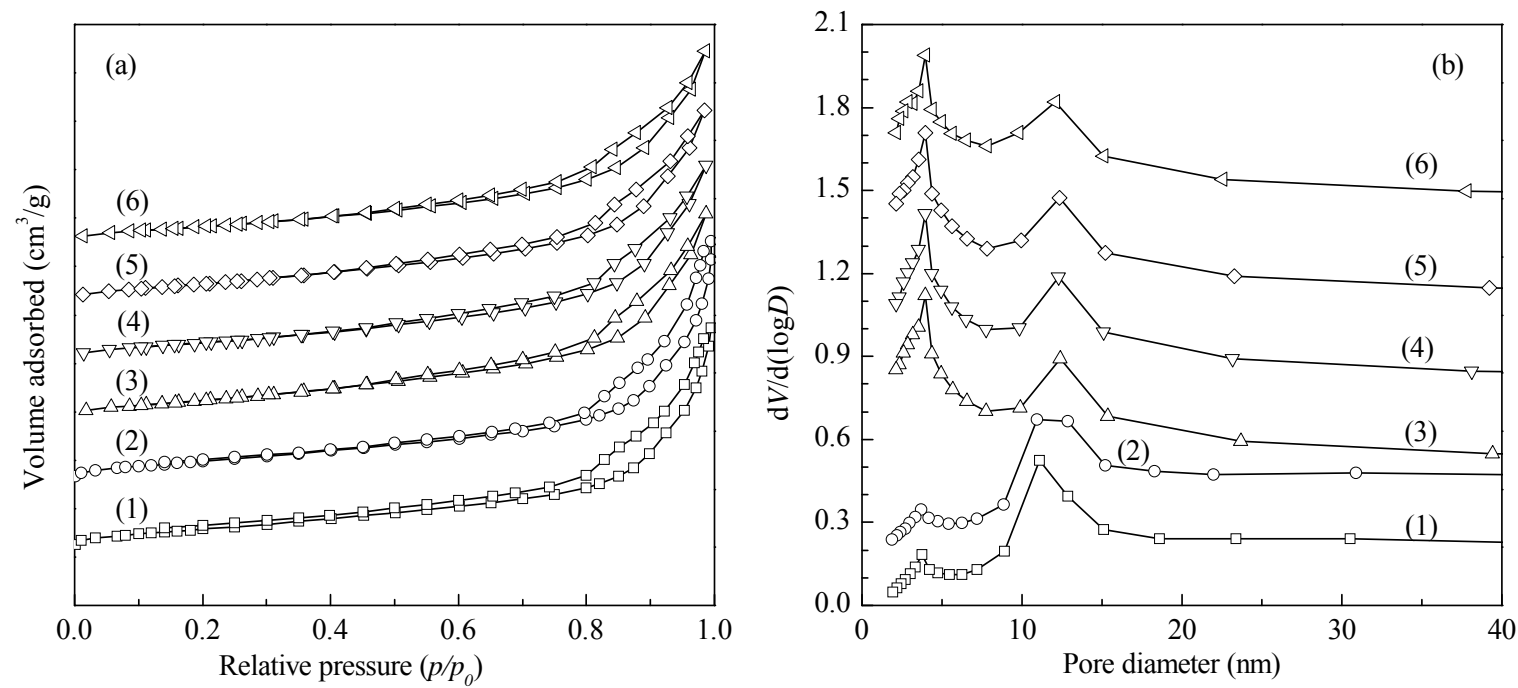

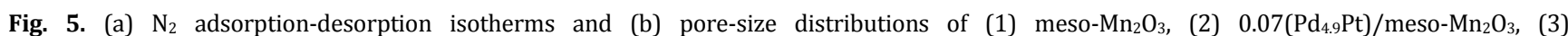
$0.72\left(\mathrm{Pd}_{5.1} \mathrm{Pt}\right) /$ meso- $\mathrm{Mn}_{2} \mathrm{O}_{3}$, (4) 1.41( $\left.\mathrm{Pd}{ }_{5.1} \mathrm{Pt}\right) /$ meso- $\mathrm{Mn}_{2} \mathrm{O}_{3},(5) 1.40 \mathrm{Pd} / \mathrm{meso}-\mathrm{Mn}_{2} \mathrm{O}_{3}$, and (6) 1.42Pt/meso- $\mathrm{Mn}_{2} \mathrm{O}_{3}$.

calcination at $600{ }^{\circ} \mathrm{C}$ for $6 \mathrm{~h}$. During impregnation and calcination, changes in the porous structure occurred and the quality
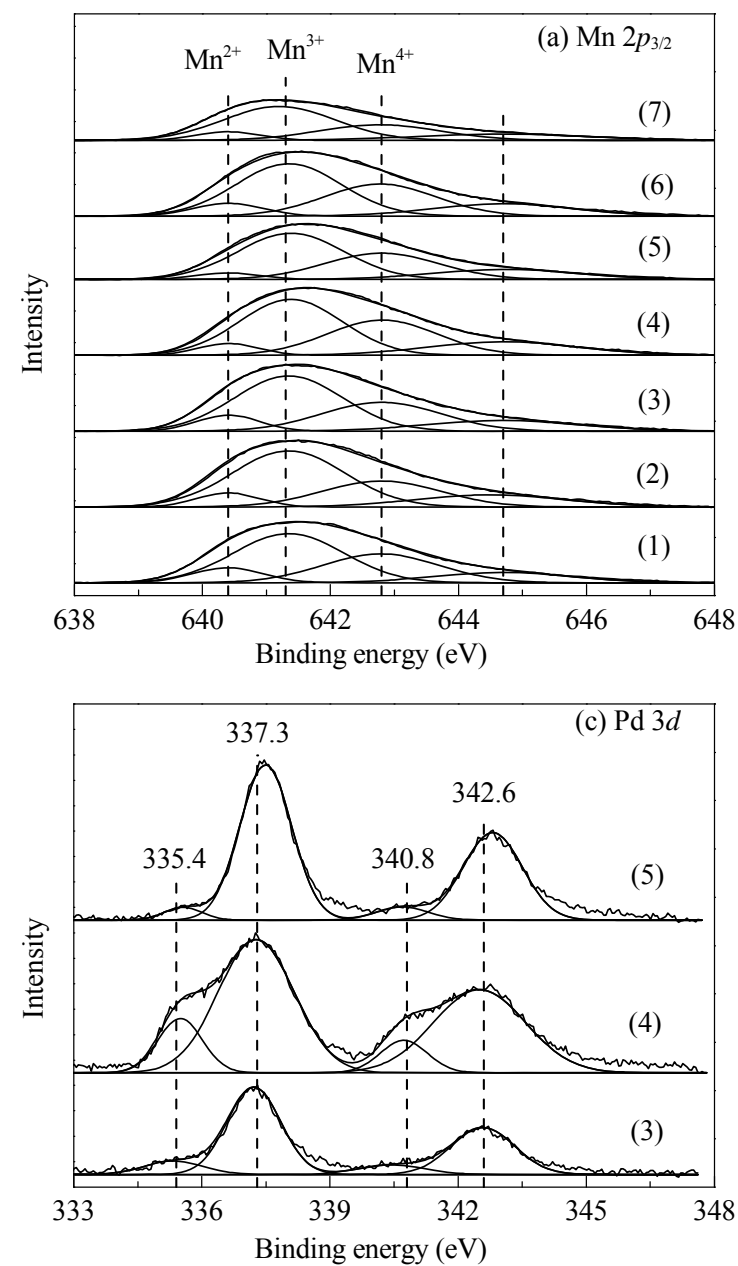

of the mesoporous structure decreased, leading to changes in the surface areas of the samples.
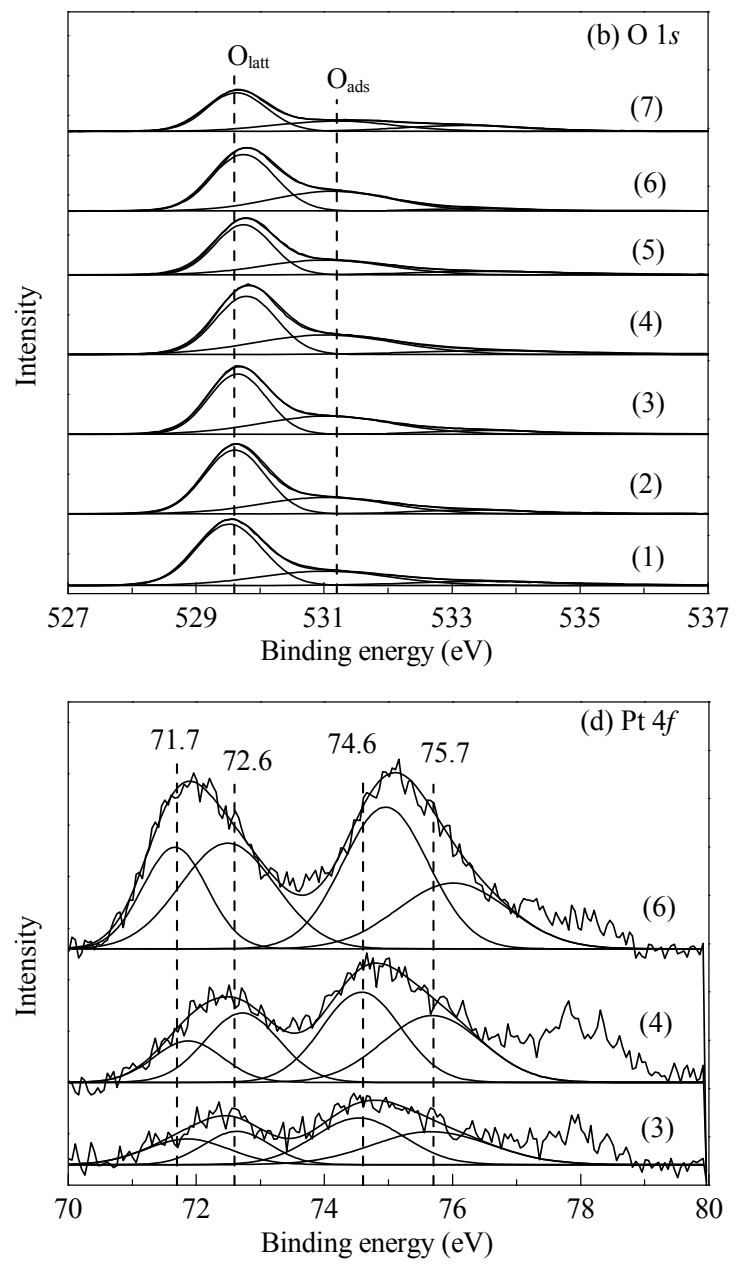

Fig. 6. (a) Mn 2p $p_{3 / 2}$, (b) $01 s$, (c) Pd $3 d$, and (d) Pt $4 f \mathrm{XPS}$ of (1) meso- $\mathrm{Mn}_{2} \mathrm{O}_{3}$, (2) $0.07\left(\mathrm{Pd}_{4.9} \mathrm{Pt}\right) / \mathrm{meso}^{-} \mathrm{Mn}_{2} \mathrm{O}_{3}$, (3) $0.72\left(\mathrm{Pd}_{5.1} \mathrm{Pt}\right) / \mathrm{meso}-\mathrm{Mn} \mathrm{O}_{3},(4)$

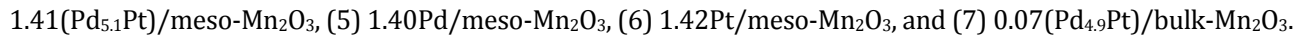




\subsection{Surface composition, metal oxidation state, and oxygen species}

XPS is an effective technique for investigating the surface element contents, metal oxidation states, and adsorbed oxygen species of an oxide catalyst. Fig. 6 shows the Mn 2p $p_{3 / 2}, 01 s$, Pd $3 d$, and Pt $4 f$ XPS of the samples. Each sample gave an asymmetric Mn 2p $p_{3 / 2}$ XPS signal (Fig. 6(a)), which was decomposed to three components with $\mathrm{BE}=640.0,641.3$, and $642.8 \mathrm{eV}$ together with a weak shake-up satellite at $\mathrm{BE}=644.7 \mathrm{eV}$, assignable to surface $\mathrm{Mn}^{2+}, \mathrm{Mn}^{3+}$, and $\mathrm{Mn}^{4+}$ species [32,33], respectively. Fig. 6(b) shows that each sample gave a broad, asymmetric $01 s$ XPS peak, which was decomposed into two components, at $\mathrm{BE}=529.6$ and $531.2 \mathrm{eV}$, ascribable to surface lattice oxygen $\left(\mathrm{O}_{\text {latt }}\right)$ and adsorbed oxygen $\left(\mathrm{O}_{\text {ads }}\right.$, e.g., $\mathrm{O}_{2}{ }^{-}, \mathrm{O}_{2}{ }^{2-}$, or $\mathrm{O}^{-}$) species [21,34], respectively. Curve fitting enabled deconvolution of the asymmetric Pd $3 d$ and $\mathrm{Pt} 4 f$ XPS signals of 0.72( $\left.\mathrm{Pd} \mathrm{P}_{5.1} \mathrm{Pt}\right) / \mathrm{meso}-\mathrm{Mn}_{2} \mathrm{O}_{3}, \quad 1.41\left(\mathrm{Pd}_{5.1} \mathrm{Pt}\right) / \mathrm{meso}-\mathrm{Mn}_{2} \mathrm{O}_{3}$, $1.40 \mathrm{Pd} / \mathrm{meso}-\mathrm{Mn}_{2} \mathrm{O}_{3}$, and $1.42 \mathrm{Pt} / \mathrm{meso}-\mathrm{Mn}_{2} \mathrm{O}_{3}$ into four components, at $\mathrm{BE}=335.4,337.3,340.8$, and $342.6 \mathrm{eV}$ and at $\mathrm{BE}=$ 71.7, 72.6, 74.6, and $75.7 \mathrm{eV}$ (Fig. 6(c) and (d)), respectively. The signals at $\mathrm{BE}=335.5$ and $340.8 \mathrm{eV}$ are assigned to surface metallic $\mathrm{Pd}^{0}$ species and those at $\mathrm{BE}=337.8$ and $342.9 \mathrm{eV}$ are attributed to surface $\mathrm{Pd}^{2+}$ species [35]. Similarly, the components at $\mathrm{BE}=71.7 \mathrm{eV}$ and $74.6 \mathrm{eV}$ are ascribed to surface metallic $\mathrm{Pt}^{0}$ species, and those at $\mathrm{BE}=72.6 \mathrm{eV}$ and $75.7 \mathrm{eV}$ are ascribed to surface oxidized $\mathrm{Pt}\left(\mathrm{Pt}^{2+}\right)[36,37]$. The Pd $3 d$ and $\mathrm{Pt} 4 f$ XPS of the other samples are not shown because their weak signals could not be decomposed accurately.

XPS was used for quantitative analysis of the samples to determine the surface element contents; the results are summarized in Table 2. The $\mathrm{O}_{\text {ads }} / \mathrm{O}_{\text {latt }}$ molar ratios decreased in the order $1.41(\mathrm{Pd} 5.1 \mathrm{Pt}) /$ meso- $\mathrm{Mn}_{2} \mathrm{O}_{3}(0.77)>1.40 \mathrm{Pd} /$ meso- $\mathrm{Mn}_{2} \mathrm{O}_{3}$ $(0.69)>0.72\left(\mathrm{Pd}_{5.1} \mathrm{Pt}\right) /$ meso $^{-\mathrm{Mn}_{2} \mathrm{O}_{3}}(0.65)>$ $1.42 \mathrm{Pt} / \mathrm{meso}-\mathrm{Mn}_{2} \mathrm{O}_{3}(0.63)>0.07\left(\mathrm{Pd}{ }_{4.9} \mathrm{Pt}\right) /$ meso- $\mathrm{Mn}_{2} \mathrm{O}_{3}(0.53)$ $>0.07\left(\mathrm{Pd}{ }_{4.9} \mathrm{Pt}\right) /$ bulk- $\mathrm{Mn}_{2} \mathrm{O}_{3}(0.52)>$ meso- $\mathrm{Mn}_{2} \mathrm{O}_{3}$ (0.45); this sequence corresponds to the order of the catalytic performances (discussed below).

A catalyst with a higher adsorbed oxygen species concentration promotes redox-based reactions [38-40]. Generally, $\mathrm{O}_{2}$ molecules can be adsorbed at the oxygen vacancies of a metal oxide [41]. Pd, Pt, or Pd-Pt loading enhanced the adsorbed oxygen species concentrations of the samples; $1.41\left(\mathrm{Pd}_{5.1} \mathrm{Pt}\right) /$ meso- $\mathrm{Mn}_{2} \mathrm{O}_{3}$ had the highest adsorbed oxygen species concentration, and therefore gave the best catalytic

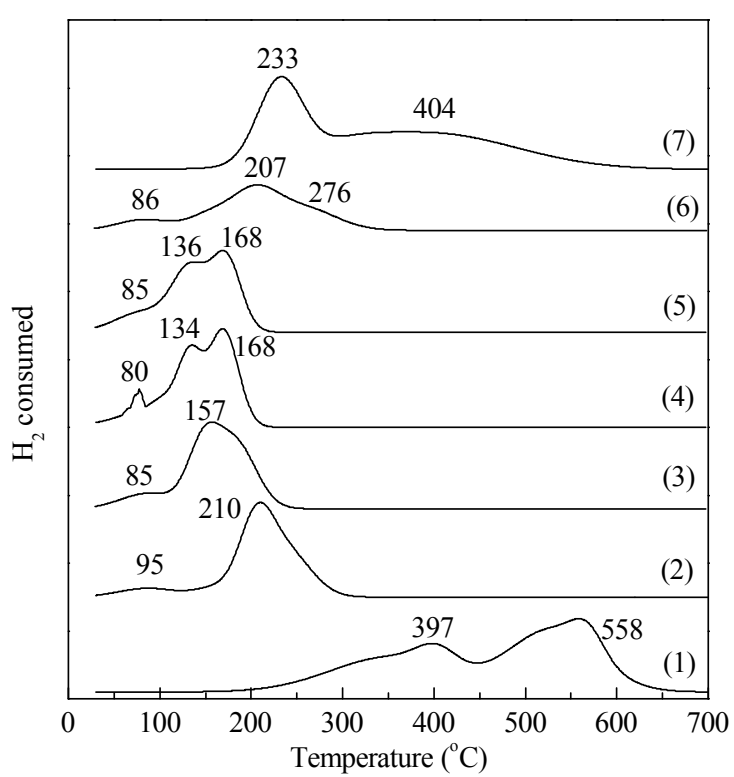

Fig. 7. $\mathrm{H}_{2}$-TPR profiles of (1) meso- $\mathrm{Mn}_{2} \mathrm{O}_{3}$, (2) $0.07\left(\mathrm{Pd}_{4.9} \mathrm{Pt}\right) / \mathrm{meso}-\mathrm{Mn}_{2} \mathrm{O}_{3}$, (3) $0.72\left(\mathrm{Pd}_{5.1} \mathrm{Pt}\right) /$ meso- $\mathrm{Mn}_{2} \mathrm{O}_{3}$, $1.41\left(\mathrm{Pd}_{5.1} \mathrm{Pt}\right) / \mathrm{meso}-\mathrm{Mn}_{2} \mathrm{O}_{3}$, (5) $1.40 \mathrm{Pd} /$ meso- $-\mathrm{Mn}_{2} \mathrm{O}_{3}$, 1.42Pt/meso- $\mathrm{Mn}_{2} \mathrm{O}_{3}$, and (7) 0.07( $\left.\mathrm{Pd} 4.9 \mathrm{Pt}\right) / \mathrm{bulk}-\mathrm{Mn}_{2} \mathrm{O}_{3}$.

performance. Strong interactions can occur between the noble-metal or alloy NPs and the $\mathrm{Mn}_{2} \mathrm{O}_{3}$ support (possibly via the reaction $\mathrm{Pd}(\mathrm{Pt}$ or $\mathrm{Pd}-\mathrm{Pt})+2 \mathrm{Mn}^{4+} \rightarrow \mathrm{Pd}^{2+}\left(\mathrm{Pt}^{2+}\right.$ or $\left.\mathrm{Pd}^{2+}-\mathrm{Pt}^{2+}\right)+$ $2 \mathrm{Mn}^{3+}$ ), therefore the surface $\mathrm{Mn}^{4+} / \mathrm{Mn}^{3+}$ molar ratios were similar (0.60-0.67) at similar loadings ((1.40-1.42) wt\%) of Pd, Pt, or Pd-Pt NPs.

\subsection{Low-temperature reducibility}

According to the literature [32,42], the reduction of manganese oxides can be divided into consecutive steps: $\mathrm{Mn}_{2} \mathrm{O}_{3} \rightarrow$ $\mathrm{Mn}_{3} \mathrm{O}_{4} \rightarrow \mathrm{MnO}$. However, the reduction peaks in the $\mathrm{H}_{2}$-TPR profile may also arise from reduction of species in different local environments [42]. Fig. 7 shows the $\mathrm{H}_{2}$-TPR profiles of the samples, and their $\mathrm{H}_{2}$ consumptions are summarized in Table 2.

There were two main reduction peaks, centered at 397 and $558{ }^{\circ} \mathrm{C}$, for meso- $\mathrm{Mn}_{2} \mathrm{O}_{3}$, attributable to the reduction of $\mathrm{Mn}_{2} \mathrm{O}_{3}$ to $\mathrm{Mn}_{3} \mathrm{O}_{4}$ and of $\mathrm{Mn}_{3} \mathrm{O}_{4}$ to $\mathrm{MnO}[32,42,43]$, respectively. After noble-metal loading, the reduction peaks of the samples shifted to lower temperatures, particularly in the case of 1.41 $\left(\mathrm{Pd}_{5.1} \mathrm{Pt}\right) /$ meso- $\mathrm{Mn}_{2} \mathrm{O}_{3}$. This indicates improved

Table 2

Surface element contents of samples and $\mathrm{H}_{2}$-TPR results.

\begin{tabular}{|c|c|c|c|c|c|c|c|}
\hline \multirow{2}{*}{ Sample } & \multicolumn{4}{|c|}{ Surface element composition (molar ratio) } & \multicolumn{3}{|c|}{$\mathrm{H}_{2}$ consumption (mmol/g) } \\
\hline & $\mathrm{Mn}^{4+} / \mathrm{Mn}^{3+}$ & $\mathrm{O}_{\text {ads }} / \mathrm{O}_{\text {latt }}$ & $\mathrm{Pd}^{2+} / \mathrm{Pd}^{0}$ & $\mathrm{Pt}^{2+} / \mathrm{Pt}^{0}$ & Below $120^{\circ} \mathrm{C}$ & Above $120^{\circ} \mathrm{C}$ & Total \\
\hline meso- $\mathrm{Mn}_{2} \mathrm{O}_{3}$ & 0.65 & 0.45 & - & - & - & 14.85 & 14.85 \\
\hline $0.07\left(\mathrm{Pd}_{4.9} \mathrm{Pt}\right) /$ meso- $\mathrm{Mn}_{2} \mathrm{O}_{3}$ & 0.48 & 0.53 & - & - & 0.68 & 12.21 & 12.89 \\
\hline $0.72\left(\mathrm{Pd}_{5.1} \mathrm{Pt}\right) /$ meso- $\mathrm{Mn}_{2} \mathrm{O}_{3}$ & 0.57 & 0.65 & 5.40 & 0.96 & 1.19 & 12.00 & 13.19 \\
\hline 1.41 $\left(\mathrm{Pd}_{5.1} \mathrm{Pt}\right) /$ meso- $\mathrm{Mn}_{2} \mathrm{O}_{3}$ & 0.67 & 0.77 & 4.50 & 1.18 & 2.34 & 11.81 & 14.15 \\
\hline $1.40 \mathrm{Pd} / \mathrm{meso}-\mathrm{Mn}_{2} \mathrm{O}_{3}$ & 0.61 & 0.69 & 11.48 & - & 2.19 & 11.52 & 13.71 \\
\hline $1.42 \mathrm{Pt} / \mathrm{meso}-\mathrm{Mn}_{2} \mathrm{O}_{3}$ & 0.60 & 0.63 & - & 0.92 & 0.82 & 11.42 & 12.24 \\
\hline $0.07\left(\mathrm{Pd}_{4.9} \mathrm{Pt}\right) /$ bulk- $\mathrm{Mn}_{2} \mathrm{O}_{3}$ & 0.49 & 0.52 & - & - & - & 14.10 & 14.10 \\
\hline
\end{tabular}


low-temperature reducibility. The reduction shoulders below $120{ }^{\circ} \mathrm{C}$ can be ascribed to the reduction of oxidized noble metals, and those above $120^{\circ} \mathrm{C}$ can be assigned to the reduction of $\mathrm{Mn}_{2} \mathrm{O}_{3}$ to $\mathrm{Mn}_{3} \mathrm{O}_{4}$ or further to $\mathrm{MnO}$. The total $\mathrm{H}_{2}$ consumptions (14.10-14.85 mmol/g) of the meso- $\mathrm{Mn}_{2} \mathrm{O}_{3}$ and $0.07\left(\mathrm{Pd} \mathrm{d}_{9} \mathrm{Pt}\right) / \mathrm{bulk}-\mathrm{Mn}_{2} \mathrm{O}_{3}$ samples were close to or slightly higher than those (12.24-14.15 $\mathrm{mmol} / \mathrm{g})$ of the meso- $\mathrm{Mn}_{2} \mathrm{O}_{3}$-supported noble-metal samples; the latter gave a low-temperature (below $120^{\circ} \mathrm{C}$ ) $\mathrm{H}_{2}$ consumption of $0.68-2.34$ $\mathrm{mmol} / \mathrm{g}$, showing that the low-temperature reducibilities of the porous $\mathrm{Mn}_{2} \mathrm{O}_{3}$-supported samples were better than those of the bulk- $\mathrm{Mn}_{2} \mathrm{O}_{3}$-supported and noble-metal-free samples. The $1.41\left(\mathrm{Pd}_{5.1} \mathrm{Pt}\right) /$ meso- $-\mathrm{Mn}_{2} \mathrm{O}_{3}$ sample showed the best low-temperature reducibility.

\subsection{Catalytic performance}

In a blank experiment (only quartz sand was loaded in the microreactor), no methane conversion was detected under the conditions 2.5 vol\% $\mathrm{CH}_{4}, \mathrm{CH}_{4} / \mathrm{O}_{2}$ molar ratio $=1 / 8, \mathrm{SV}=20000$ $\mathrm{mL} /(\mathrm{g} \cdot \mathrm{h})$, less than $600{ }^{\circ} \mathrm{C}$, i.e., no homogeneous reactions occurred in the catalytic system under the conditions used. Fig. 8(a) and (b) show the catalytic activities of the obtained samples and the effect of the SV on the catalytic activity of $1.41\left(\mathrm{Pd}_{5.1} \mathrm{Pt}\right) /$ meso- $\mathrm{Mn}_{2} \mathrm{O}_{3}$ in methane combustion, respectively.

Fig. 8(a) shows that the catalytic activity increased monotonously with increasing temperature, and loading of noble-metal NPs improved the catalytic activity. At similar noble-metal NP loadings, the catalytic activity of the sample loaded with Pd-Pt alloy NPs was better than those of the samples loaded with $\mathrm{Pd}$ only $\left(1.40 \mathrm{Pd} / \mathrm{meso}-\mathrm{Mn}_{2} \mathrm{O}_{3}\right)$ or $\mathrm{Pt}$ only (1.42Pt/meso- $\left.\mathrm{Mn}_{2} \mathrm{O}_{3}\right)$. The $0.70(\mathrm{Pd} 4.9 \mathrm{Pt}) / \mathrm{meso}-\mathrm{Mn}_{2} \mathrm{O}_{3}$ sample outperformed the $0.70\left(\mathrm{Pd}_{4.9} \mathrm{Pt}\right) /$ bulk- $\mathrm{Mn}_{2} \mathrm{O}_{3}$ sample. The 1.41 $\left(\mathrm{Pd}_{5.1} \mathrm{Pt}\right) /$ meso- $-\mathrm{Mn}_{2} \mathrm{O}_{3}$ sample gave the best performance. These results show that the presence of a porous structure and the alloying of noble metals improved the catalytic activity. It is

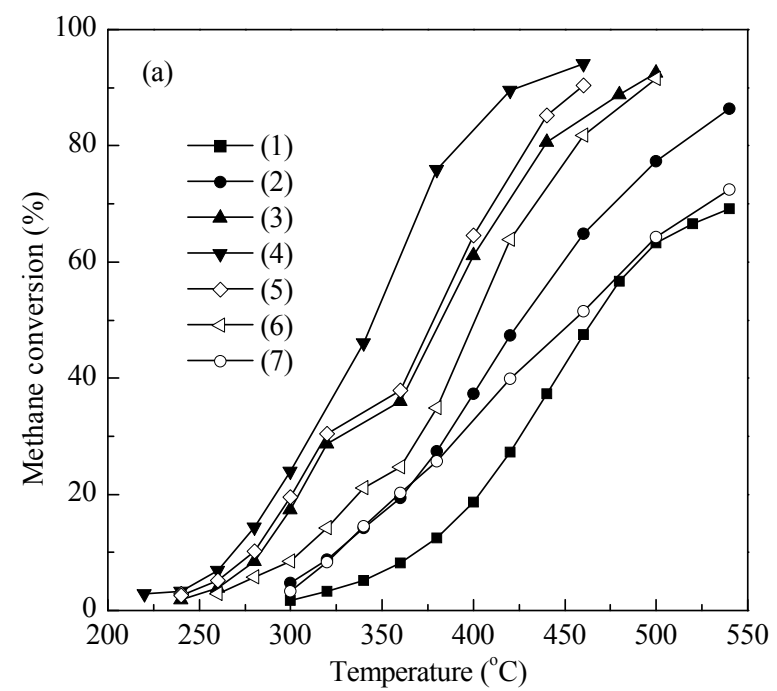

more convenient to compare the catalytic activities of the samples using $T_{10 \%}, T_{50 \%}$, and $T_{90 \%}$; these data are summarized in Table 3.

The $1.41\left(\mathrm{Pd}_{5.1} \mathrm{Pt}\right) /$ meso- $\mathrm{Mn}_{2} \mathrm{O}_{3}$ sample performed best, giving $T_{10 \%}, T_{50 \%}$, and $T_{90 \%}$ values of 265,345 , and $425^{\circ} \mathrm{C}$, respectively, at SV $=20000 \mathrm{~mL} /(\mathrm{g} \cdot \mathrm{h})$. The $T_{90 \%}$ values were $495{ }^{\circ} \mathrm{C}$ over $\quad 1.42 \mathrm{Pt} / \mathrm{meso}-\mathrm{Mn}_{2} \mathrm{O}_{3}, \quad 485 \quad{ }^{\circ} \mathrm{C} \quad$ over

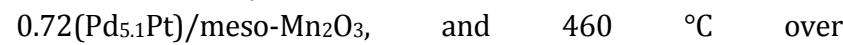
$1.40 \mathrm{Pd} / \mathrm{meso}-\mathrm{Mn}_{2} \mathrm{O}_{3}$. The methane conversion over 1.41( $\left.\mathrm{Pd}_{5.1} \mathrm{Pt}\right) /$ meso- $\mathrm{Mn}_{2} \mathrm{O}_{3}$ decreased with increasing SV (Fig. $8(\mathrm{~b})$ ), as a result of shortening of the contact time.

Generally, it is more accurate to use the turnover frequencies (TOFs) and specific reaction rates to evaluate the inherent catalytic activities. For the $\mathrm{Mn}_{2} \mathrm{O}_{3}$-supported noble-metal catalysts, noble metals and $\mathrm{Mn}_{2} \mathrm{O}_{3}$ are the active sites, and it is difficult to calculate the TOFs of such samples accurately. The TOF $_{\mathrm{M}}$ values $\left[=z C_{0} / n_{\mathrm{M}}\right.$, where $z$ is the conversion at a certain temperature, $C_{0}(\mathrm{~mol} / \mathrm{s})$ is the initial methane concentration, and $n_{\mathrm{M}}(\mathrm{mol})$ is the molar amount of metal or oxide $(\mathrm{M}=\mathrm{Pd}, \mathrm{Pt}$, Pd-Pt or $\left.\mathrm{Mn}_{2} \mathrm{O}_{3}\right)$ ] and the specific reaction rates at a typical temperature $\left(400{ }^{\circ} \mathrm{C}\right)$ were calculated based on the activity data and amounts of $\mathrm{Pd}$ and/or Pt and $\mathrm{Mn}_{2} \mathrm{O}_{3}$ in the samples; the results are summarized in Table 3. Fig. 9 shows the specific reaction rates normalized per gram of catalyst, noble metal, or $\mathrm{Mn}_{2} \mathrm{O}_{3}$. Fig. 9 and the data in Table 3 shows that 1.41 $\left(\mathrm{Pd}_{5.1} \mathrm{Pt}\right) /$ meso- $\mathrm{Mn}_{2} \mathrm{O}_{3}$ had the highest TOF $\left(1.02 \mathrm{~ms}^{-1}\right)$ for noble metal and the highest specific reaction rates (6.39 $\mu \mathrm{mol} /(\mathrm{g} \cdot \mathrm{s})$ for catalyst and $6.48 \mathrm{mmol} /(\mathrm{g} \cdot \mathrm{s})$ for $\mathrm{Mn}_{2} \mathrm{O}_{3}$ ) at 400 ${ }^{\circ} \mathrm{C}$; however, the highest TOF $\left(0.50 \mathrm{~ms}^{-1}\right)$ for $\mathrm{Mn}_{2} \mathrm{O}_{3}$ and specific reaction rate normalized per gram of noble metal (4.11 $\mathrm{mmol} /(\mathrm{g} \cdot \mathrm{s})$ ) at $400{ }^{\circ} \mathrm{C}$ were achieved over $0.07\left(\mathrm{Pd}_{4.9} \mathrm{Pt}\right) /$ meso- $\mathrm{Mn}_{2} \mathrm{O}_{3}$. The specific reaction rates normalized per gram of catalyst or $\mathrm{Mn}_{2} \mathrm{O}_{3}$ (Fig. 9(a) and (b)) changed in a similar manner to the catalytic activities of the samples. The only difference was in the case of the specific reaction rates normalized per gram of noble metal, in which the $0.07\left(\mathrm{Pd}_{4.9} \mathrm{Pt}\right) /$ meso- $\mathrm{Mn}_{2} \mathrm{O}_{3}$ and $0.07\left(\mathrm{Pd}_{4.9} \mathrm{Pt}\right) /$ bulk- $\mathrm{Mn}_{2} \mathrm{O}_{3}$ sam-

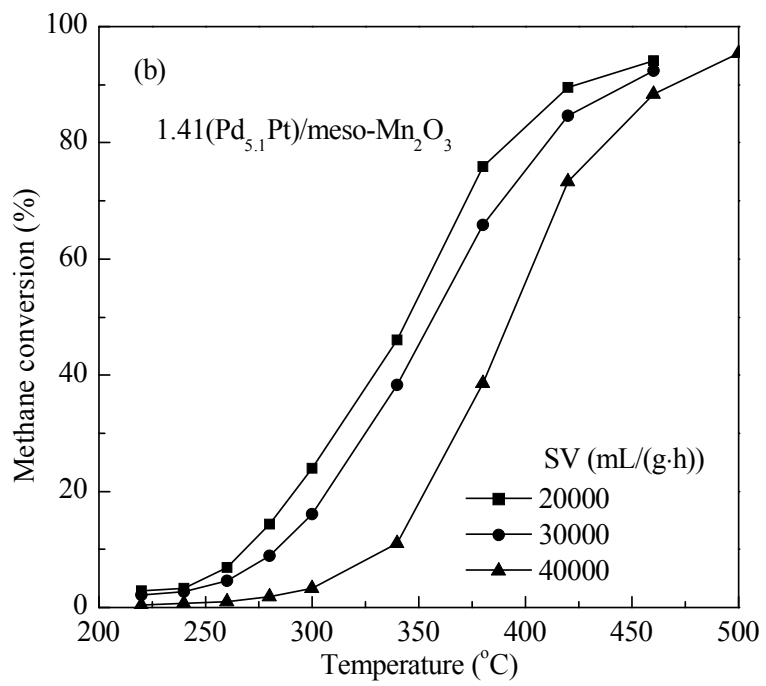

Fig. 8. (a) Methane conversion as function of reaction temperature for (1) meso- $\mathrm{Mn}_{2} \mathrm{O}_{3},(2) 0.07\left(\mathrm{Pd}{ }_{4.9} \mathrm{Pt}\right) / \mathrm{meso}-\mathrm{Mn}_{2} \mathrm{O}_{3},(3) 0.72\left(\mathrm{Pd}_{5.1} \mathrm{Pt}\right) / \mathrm{meso}-\mathrm{Mn}_{2} \mathrm{O}_{3}$, (4) $1.41\left(\mathrm{Pd}_{5.1} \mathrm{Pt}\right) / \mathrm{meso}-\mathrm{Mn}_{2} \mathrm{O}_{3}$, (5) 0.07( $\left.\mathrm{Pd}_{4.9} \mathrm{Pt}\right) /$ bulk- $\mathrm{Mn}_{2} \mathrm{O}_{3}$, (6) $1.40 \mathrm{Pd} /$ meso- $\mathrm{Mn}_{2} \mathrm{O}_{3}$, and (7) $1.42 \mathrm{Pt} / \mathrm{meso}^{-} \mathrm{Mn}_{2} \mathrm{O}_{3}$ at SV = $20000 \mathrm{~mL} /(\mathrm{g} \cdot \mathrm{h}) ; \mathrm{and}(\mathrm{b})$ effect of SV on methane oxidation over 1.41 $\left(\mathrm{Pd}_{5.1} \mathrm{Pt}\right) /$ meso- $-\mathrm{Mn}_{2} \mathrm{O}_{3}$. 
Table 3

Catalytic activities, TOF values, and specific reaction rates of samples at SV $=20000 \mathrm{~mL} /(\mathrm{g} \cdot \mathrm{h})$.

\begin{tabular}{|c|c|c|c|c|c|c|c|c|}
\hline \multirow[b]{2}{*}{ Sample } & \multicolumn{3}{|c|}{ Methane combustion activity } & \multicolumn{5}{|c|}{ Methane combustion at $400^{\circ} \mathrm{C}$} \\
\hline & $\begin{array}{l}T_{10 \%} \\
\left({ }^{\circ} \mathrm{C}\right)\end{array}$ & $\begin{array}{l}T_{50 \%} \\
\left({ }^{\circ} \mathrm{C}\right)\end{array}$ & $\begin{array}{l}T_{90 \%} \\
\left({ }^{\circ} \mathrm{C}\right)\end{array}$ & $\begin{array}{c}\text { TOF } \\
\left(\mathrm{ms}^{-1}\right)\end{array}$ & $\begin{array}{c}\mathrm{TOF}_{\mathrm{Mn} 203} \\
\left(\mathrm{~ms}^{-1}\right)\end{array}$ & $\begin{array}{l}\text { Specific reaction } \\
\text { rate for catalyst } \\
(\mu \mathrm{mol} /(\mathrm{g} \cdot \mathrm{s}))\end{array}$ & $\begin{array}{l}\text { Specific reaction } \\
\text { rate for } \mathrm{Mn}_{2} \mathrm{O}_{3} \\
(\mu \mathrm{mol} /(\mathrm{g} \cdot \mathrm{s}))\end{array}$ & $\begin{array}{c}\text { Specific reaction rate } \\
\text { for noble metal } \\
(\mathrm{mmol} /(\mathrm{g} \cdot \mathrm{s}))\end{array}$ \\
\hline meso- $\mathrm{Mn}_{2} \mathrm{O}_{3}$ & 370 & 455 & - & 0.23 & - & 1.44 & 1.44 & - \\
\hline $0.07 \mathrm{Pd}_{4.9} \mathrm{Pt} /$ meso- $\mathrm{Mn}_{2} \mathrm{O}_{3}$ & 320 & 425 & - & 0.45 & 0.50 & 2.88 & 2.88 & 4.11 \\
\hline $0.72 \mathrm{Pd}_{5.1} \mathrm{Pt} / \mathrm{meso}-\mathrm{Mn}_{2} \mathrm{O}_{3}$ & 285 & 382 & 485 & 0.75 & 0.08 & 4.70 & 4.74 & 0.65 \\
\hline 1.41Pd ${ }_{5.1} \mathrm{Pt} /$ meso- $\mathrm{Mn}_{2} \mathrm{O}_{3}$ & 265 & 345 & 425 & 1.02 & 0.05 & 6.39 & 6.48 & 0.45 \\
\hline $1.40 \mathrm{Pd} / \mathrm{meso}^{-} \mathrm{Mn}_{2} \mathrm{O}_{3}$ & 280 & 380 & 460 & 0.80 & 0.04 & 4.97 & 5.04 & 0.35 \\
\hline $1.42 \mathrm{Pt} / \mathrm{meso}-\mathrm{Mn}_{2} \mathrm{O}_{3}$ & 305 & 400 & 495 & 0.62 & 0.05 & 3.85 & 3.90 & 0.27 \\
\hline $0.07 \mathrm{Pd}_{4.9} \mathrm{Pt} /$ bulk- $\mathrm{Mn}_{2} \mathrm{O}_{3}$ & 320 & 455 & - & 0.40 & 0.04 & 2.54 & 2.54 & 3.63 \\
\hline
\end{tabular}
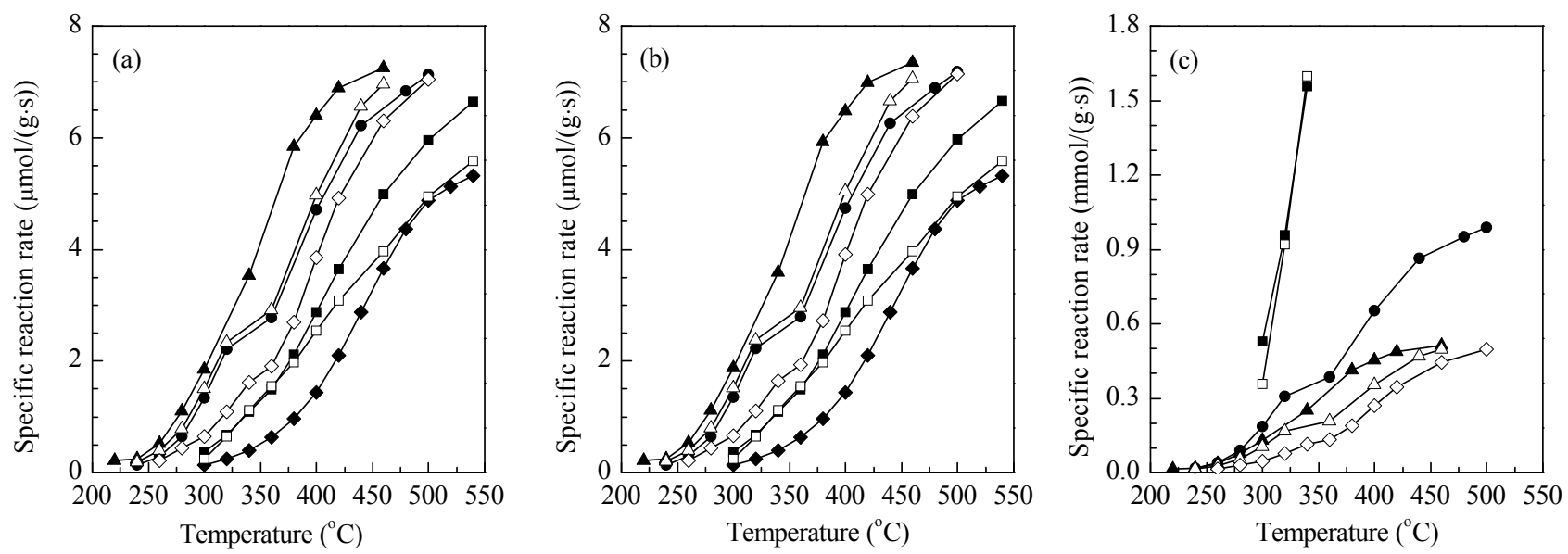

Fig. 9. Specific reaction rates normalized per gram of (a) catalyst, (b) $\mathrm{Mn}_{2} \mathrm{O}_{3}$, and (c) noble metal as a function of temperature for ( $\bullet$ ) meso-Mn $\mathrm{O}_{3}$, ( $\bullet$

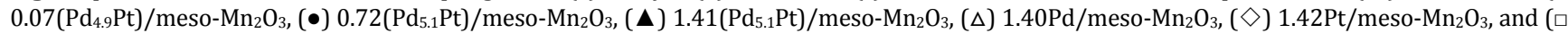
$0.07 \mathrm{Pd}_{4.9} \mathrm{Pt} /$ bulk- $\mathrm{Mn}_{2} \mathrm{O}_{3}$.

ples showed higher specific reaction rates normalized per gram of noble metal above $300{ }^{\circ} \mathrm{C}$ (Fig. 9(c)), possibly because of the low loadings of noble-metal NPs. These results also suggest that other factors (e.g., adsorbed oxygen species concentration, low-temperature reducibility, and noble metal-support interactions) affected the catalytic performances of the supported samples.

Fig. 10 shows the methane consumption rates and $\mathrm{TOF}_{\mathrm{Mn} 203}$ values of the samples at 300 and $400{ }^{\circ} \mathrm{C}$ as a function of the $\mathrm{O}_{\text {ads }} / \mathrm{O}_{\text {latt }}$ molar ratio. Either the methane consumption rate or the $\mathrm{TOF}_{\mathrm{Mn} 203}$ increased with increasing $\mathrm{O}_{\text {ads }}$ concentration, showing that a higher $\mathrm{O}_{\text {ads }}$ concentration enhanced the catalytic performance [44].

Hutchings and coworkers [45] pointed out that the $\mathrm{Au}$ in supported Au-Pd alloy catalysts can act as an electronic promoter for Pd. It has also been reported that the performances of bimetallic $\mathrm{Au}-\mathrm{Pd} / \mathrm{CeO}_{2}$ catalysts in toluene oxidation are better than those of single-metal $\mathrm{Au} / \mathrm{CeO}_{2}$ or $\mathrm{Pd} / \mathrm{CeO}_{2}$ catalysts because of a mutual promotional effect [46]. In the present work, $1.41\left(\mathrm{Pd}_{5.1} \mathrm{Pt}\right) /$ meso- $\mathrm{Mn}_{2} \mathrm{O}_{3}$ performed better than $1.40 \mathrm{Pd} /$ meso- $\mathrm{Mn}_{2} \mathrm{O}_{3}$ or $1.42 \mathrm{Pt} /$ meso- $\mathrm{Mn}_{2} \mathrm{O}_{3}$, possibly because of Pd-Pt interactions. PdO is usually considered to be an activity-controlling factor in catalyzing hydrocarbon oxidation. According to the literature $[47,48]$, however, a small amount of metallic Pd on the PdO particles in pure Pd catalysts enhances the activity compared with that of fully oxidized PdO particles. A good contact surface between Pd and PdO particles is therefore important. In the case of supported bimetallic Pd-Pt catalysts, the metallic phase is retained, even in an oxidizing atmosphere, because of Pd-Pt alloy formation. The catalytic activity of $1.41\left(\mathrm{Pd}_{5.1} \mathrm{Pt}\right) /$ meso- $\mathrm{Mn}_{2} \mathrm{O}_{3}$ might therefore be better than that of a monometallic Pd catalyst, despite the slightly lower surface PdO content. Another possible reason for the higher activity of the supported Pd-Pt alloy catalyst is easier oxygen adsorption and activation than on the $\mathrm{PdO}$ phase.

In recent years, a number of studies of methane combustion over Mn-based and supported noble-metal catalysts have been reported in the literature; the results are shown in Table 4.

Clearly, the $T_{50 \%}$ and $T_{90 \%}$ values over

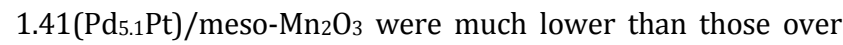
$\mathrm{La}_{0.7} \mathrm{Ag}_{0.3} \mathrm{MnO}_{3}$ [49], $\mathrm{La}_{0.7} \mathrm{Sr}_{0.3} \mathrm{MnO}_{3}$ [49], $\mathrm{La}_{0.7} \mathrm{Ce}_{0.3} \mathrm{MnO}_{3}$ [49], $1.0 \mathrm{wt} \% \mathrm{Pd} / \mathrm{Al}_{2} \mathrm{O}_{3}$ [50], $1.0 \mathrm{wt} \% \mathrm{Pd} / \mathrm{ZrO}_{2}$ [50], $1 \mathrm{~mol} \% \mathrm{Pd}$ in LaMnPd [51], 2 mol\% Rh in LaMnRh [51], and 1.1 wt\% $\mathrm{Pt} / 3 \mathrm{DOM} \mathrm{Ce}_{0.6} \mathrm{Zr}_{0.3} \mathrm{Y}_{0.1} \mathrm{O}_{2}$ [52]. The specific activity over $1.41\left(\mathrm{Pd}_{5.1} \mathrm{Pt}\right) /$ meso- $\mathrm{Mn}_{2} \mathrm{O}_{3}$ was much higher than those over $\mathrm{La}_{0.7} \mathrm{Ag}_{0.3} \mathrm{MnO}_{3}$ [49], $\mathrm{La}_{0.7} \mathrm{Sr}_{0.3} \mathrm{MnO}_{3}$ [49], $\mathrm{La}_{0.7} \mathrm{Ce}_{0.3} \mathrm{MnO}_{3}$ [49], 1 mol\% Pd in LaMnPd [51], and $2 \mathrm{~mol} \% \mathrm{Rh}$ in LaMnRh [51], and close to those over $1.1 \mathrm{wt} \% \mathrm{Pt} / 3 \mathrm{DOM} \mathrm{Ce}_{0.6} \mathrm{Zr}_{0.3} \mathrm{Y}_{0.1} \mathrm{O}_{2}$ [52], but lower than those over $1.0 \mathrm{wt} \% \mathrm{Pd} / \mathrm{Al}_{2} \mathrm{O}_{3}$ [50] and $1.0 \mathrm{wt} \%$ $\mathrm{Pd} / \mathrm{ZrO}_{2}[50]$. 

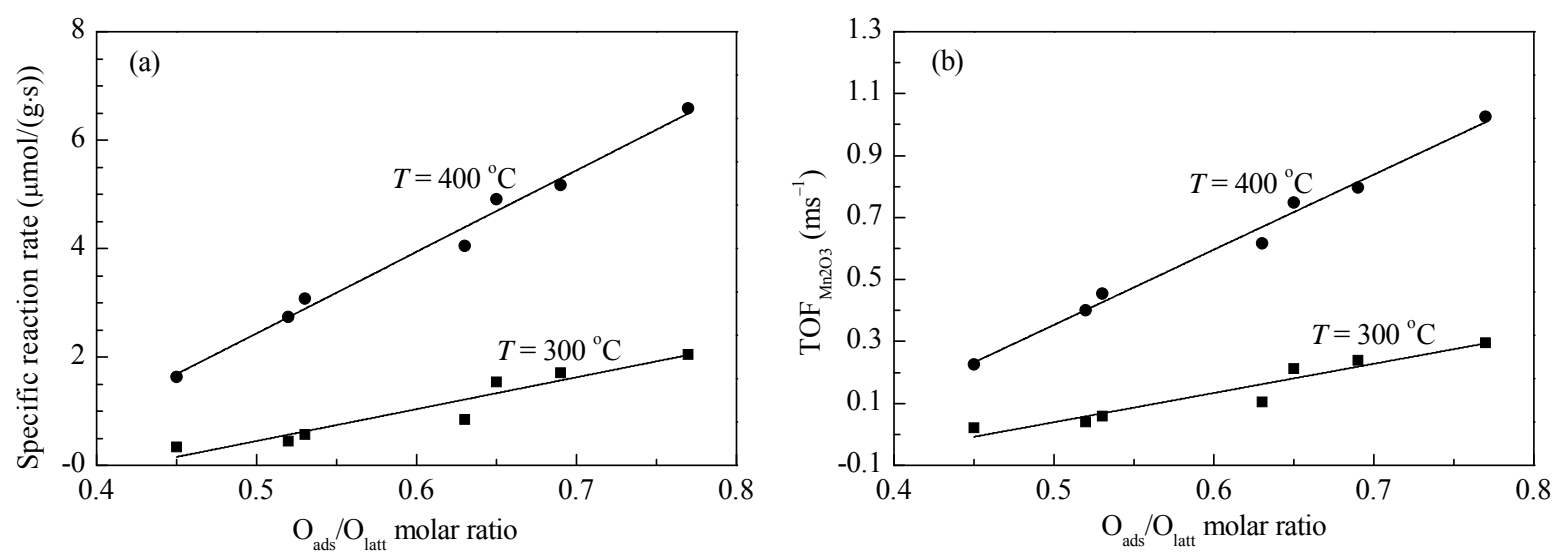

Fig. 10. (a) Methane consumption rates and (b) $\mathrm{TOF}_{\mathrm{Mn} 203}$ values at various temperatures as function of $\mathrm{O}_{\text {ads }} / \mathrm{O}_{\text {latt }}$ molar ratios of samples.

Table 4

Comparison of methane oxidation activities of samples with those reported in the literature.

\begin{tabular}{|c|c|c|c|c|c|c|}
\hline Catalyst & Reaction condition & $\begin{array}{l}T_{50 \%} \\
\left({ }^{\circ} \mathrm{C}\right) \\
\end{array}$ & $\begin{array}{l}T_{90 \%} \\
\left({ }^{\circ} \mathrm{C}\right) \\
\end{array}$ & $\begin{array}{c}\text { Specific activity at } T_{50 \%} \\
(\mathrm{~mol} /(\mathrm{g} \cdot \mathrm{min}))\end{array}$ & $\begin{array}{c}\text { Specific activity at } T_{90 \%} \\
(\mathrm{~mol} /(\mathrm{g} \cdot \mathrm{min}))\end{array}$ & Ref. \\
\hline $1.41 \mathrm{Pd}_{5.1} \mathrm{Pt} / \mathrm{meso}-\mathrm{Mn}_{2} \mathrm{O}_{3}$ & $2.5 \% \mathrm{CH}_{4}, \mathrm{SV}=20000 \mathrm{~mL} /(\mathrm{g} \cdot \mathrm{h})$ & 345 & 425 & $2.28 \times 10^{-4}$ & $4.10 \times 10^{-4}$ & This work \\
\hline $\mathrm{La} 0.7 \mathrm{Ag}_{0.3} \mathrm{MnO}_{3}$ & $1 \% \mathrm{CH}_{4}, \mathrm{SV}=10000 \mathrm{~mL} /(\mathrm{g} \cdot \mathrm{h})$ & 690 & 750 & $1.81 \times 10^{-5}$ & $2.66 \times 10^{-5}$ & [49] \\
\hline $\mathrm{La}_{0.7} \mathrm{Sr}_{0.3} \mathrm{MnO}_{3}$ & $1 \% \mathrm{CH}_{4}, \mathrm{SV}=10000 \mathrm{~mL} /(\mathrm{g} \cdot \mathrm{h})$ & 720 & 780 & $1.69 \times 10^{-5}$ & $2.57 \times 10^{-5}$ & [49] \\
\hline $\mathrm{La}_{0.7} \mathrm{Ce}_{0.3} \mathrm{MnO}_{3}$ & $1 \% \mathrm{CH}_{4}, \mathrm{SV}=10000 \mathrm{~mL} /(\mathrm{g} \cdot \mathrm{h})$ & 740 & 810 & $1.68 \times 10^{-5}$ & $2.52 \times 10^{-5}$ & [49] \\
\hline $1.0 \mathrm{wt} \% \mathrm{Pd} / \mathrm{Al}_{2} \mathrm{O}_{3}$ & $5 \% \mathrm{CH}_{4}, \mathrm{SV}=30000 \mathrm{~mL} /(\mathrm{g} \cdot \mathrm{h})$ & 640 & 710 & $3.57 \times 10^{-4}$ & $4.72 \times 10^{-4}$ & [50] \\
\hline $1.0 \mathrm{wt} \% \mathrm{Pd} / \mathrm{ZrO}_{2}$ & $5 \% \mathrm{CH}_{4}, \mathrm{SV}=30000 \mathrm{~mL} /(\mathrm{g} \cdot \mathrm{h})$ & 600 & 650 & $3.88 \times 10^{-4}$ & $5.15 \times 10^{-4}$ & [50] \\
\hline $1 \mathrm{~mol} \%$ Pd, LaMnPd & $1 \% \mathrm{CH}_{4}, \mathrm{SV}=5000 \mathrm{~mL} /(\mathrm{g} \cdot \mathrm{h})$ & 425 & 475 & $1.21 \times 10^{-5}$ & $1.85 \times 10^{-5}$ & [51] \\
\hline $2 \mathrm{~mol} \% \mathrm{Rh}, \mathrm{LaMnRh}$ & $1 \% \mathrm{CH}_{4}, \mathrm{SV}=5000 \mathrm{~mL} /(\mathrm{g} \cdot \mathrm{h})$ & 445 & 515 & $1.17 \times 10^{-5}$ & $1.79 \times 10^{-5}$ & [51] \\
\hline $1.1 \mathrm{wt} \% \mathrm{Pt} / 3 \mathrm{DOM} \mathrm{Ce} \mathrm{Ce}_{0.6} \mathrm{Zr}_{0.3} \mathrm{Y}_{0.1} \mathrm{O}_{2}$ & $2 \% \mathrm{CH}_{4}, \mathrm{SV}=30000 \mathrm{~mL} /(\mathrm{g} \cdot \mathrm{h})$ & 479 & 598 & $2.41 \times 10^{-4}$ & $4.33 \times 10^{-4}$ & [52] \\
\hline
\end{tabular}

Methane oxidation over the Pd-based catalysts can proceed via the Mars-van Krevelen mechanism, in which the reaction takes place via a redox cycle of the catalyst $[19,53,54]$. At low temperatures, methane can react with chemisorbed oxygen to yield $\mathrm{CO}_{2}$ and $\mathrm{H}_{2} \mathrm{O}$; however, at higher temperatures, the lattice oxygens in oxidized noble metals are involved in methane oxidation, resulting in catalyst reduction. The gas-phase $\mathrm{O}_{2}$ molecules can be activated at the oxygen vacancies of $\mathrm{Mn}_{2} \mathrm{O}_{3}$ or near the interface between oxidized $\mathrm{Pd}$ and/or $\mathrm{Pt}$ and $\mathrm{Mn}_{2} \mathrm{O}_{3}$ to give active oxygen species, replenishing the lattice oxygens of oxidized Pd and/or Pt consumed in methane oxidation and re-oxidizing the reduced catalyst. In the case of the $\mathrm{Mn}_{2} \mathrm{O}_{3}$-supported Pd-Pt alloy catalysts, the metallic phase is maintained, even in an oxidizing atmosphere, because of formation of a Pd-Pt alloy, resulting in better activity compared with those of the $\mathrm{Mn}_{2} \mathrm{O}_{3}$-supported Pd or Pt catalyst. Alloying of Pd with Pt significantly promotes the adsorption and activation of oxygen, possibly enhancing the migration of activated oxygen to the noble-metal alloy- $\mathrm{Mn}_{2} \mathrm{O}_{3}$ interface. The excellent catalytic activity of $1.41\left(\mathrm{Pd}_{5.1} \mathrm{Pt}\right) /$ meso- $\mathrm{Mn}_{2} \mathrm{O}_{3}$ could result from its enhanced oxygen activation ability and better low-temperature reducibility.

The catalytic stability was examined by performing on-stream methane combustion over $1.41\left(\mathrm{Pd}_{5.1} \mathrm{Pt}\right) / \mathrm{meso}-\mathrm{Mn}_{2} \mathrm{O}_{3}$ at $425{ }^{\circ} \mathrm{C}$ and $\mathrm{SV}=20000 \mathrm{~mL} /(\mathrm{g} \cdot \mathrm{h})$ for $25 \mathrm{~h}$; the results are shown in Fig. 11. No significant loss in catalytic activity was observed within $25 \mathrm{~h}$ of on-stream reaction. The $1.41\left(\mathrm{Pd}_{5.1} \mathrm{Pt}\right) /$ meso- $\mathrm{Mn}_{2} \mathrm{O}_{3}$ sample was therefore cat- alytically stable under the reaction conditions used.

\subsection{Effects of $\mathrm{SO}_{2}, \mathrm{CO}_{2}, \mathrm{H}_{2} \mathrm{O}$, and $\mathrm{NO}$ addition on catalytic activity}

The effects of $\mathrm{SO}_{2}, \mathrm{CO}_{2}$, water vapor, and $\mathrm{NO}$ on the catalytic activity were investigated by performing methane combustion over $1.41\left(\mathrm{Pd}_{5.1} \mathrm{Pt}\right) / \mathrm{meso}-\mathrm{Mn}_{2} \mathrm{O}_{3}$ in the presence of $100 \mathrm{ppm}$ $\mathrm{SO}_{2}, 5.0$ vol\% $\mathrm{CO}_{2}, 3.0$ vol $\% \mathrm{H}_{2} \mathrm{O}$, or 1.0 vol\% NO; the results are shown in Fig. 12(a).

It is clear that the catalytic activities of

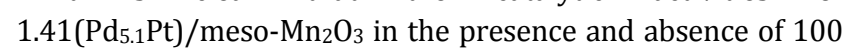
ppm $\mathrm{SO}_{2}$ or 5.0 vol\% $\mathrm{CO}_{2}$ were similar, i.e., this catalyst was

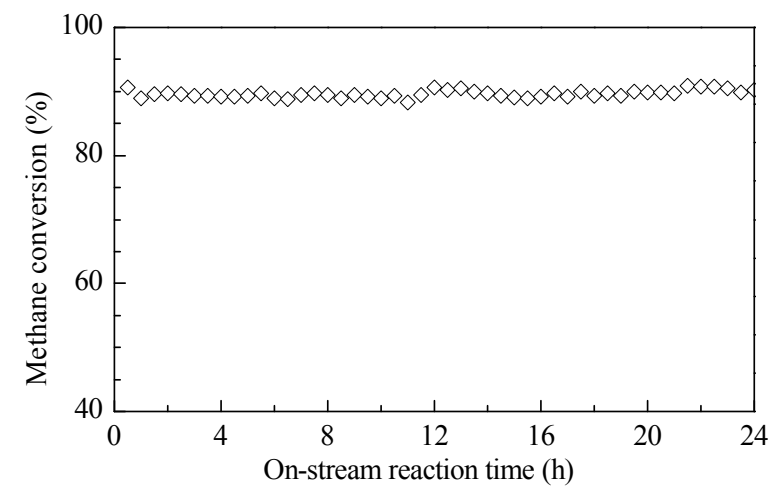

Fig. 11. Methane conversion versus on-stream methane oxidation time over 1.41( $\left(\mathrm{Pd}_{5.1} \mathrm{Pt}\right) / \mathrm{meso}-\mathrm{Mn}_{2} \mathrm{O}_{3}$ at $\mathrm{SV}=20000 \mathrm{~mL} /(\mathrm{g} \cdot \mathrm{h})$ and at $425^{\circ} \mathrm{C}$. 

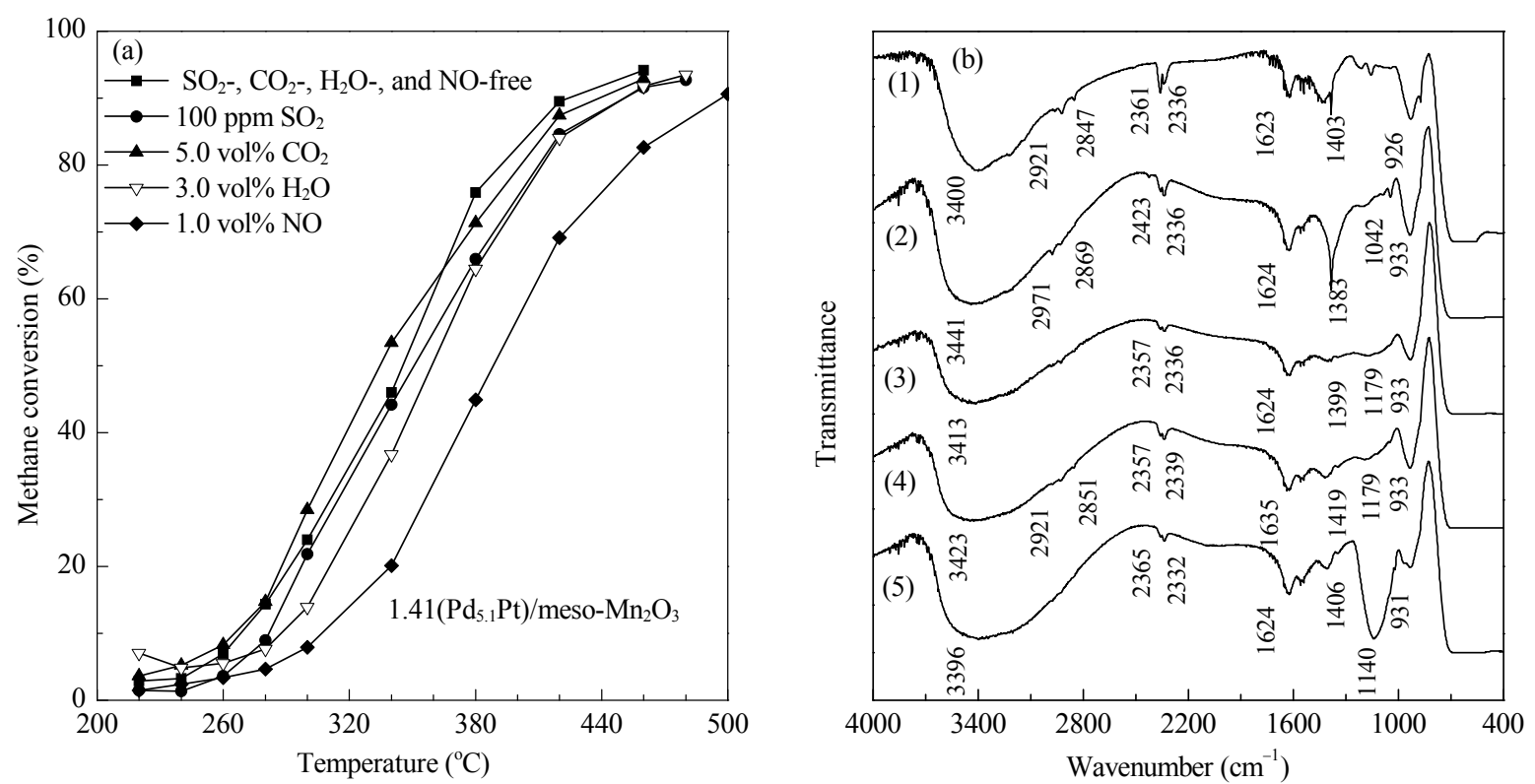

Fig. 12. (a) Effects of 100 ppm SO $2,5.0$ vol\% $\mathrm{CO}_{2}, 3.0$ vol\% $\mathrm{H}_{2} \mathrm{O}$, and 1.0 vol\% NO on methane conversion at SV = $20000 \mathrm{~mL} /(\mathrm{g}$.h); and (b) FT-IR spectra of $1.41\left(\mathrm{Pd}_{5.1} \mathrm{Pt}\right) / \mathrm{meso}-\mathrm{Mn}_{2} \mathrm{O}_{3}(1)$ after activation in $\mathrm{O}_{2}$ flow $(16.6 \mathrm{~mL} / \mathrm{min})$ at $250{ }^{\circ} \mathrm{C}$ for $1 \mathrm{~h}$ and after methane combustion in presence of $(2) 100$ ppm $\mathrm{SO}_{2}$, (3) 5.0 vol\% $\mathrm{CO}_{2}$, (4) 3.0 vol\% $\mathrm{H}_{2} \mathrm{O}$, or (5) 1.0 vol\% NO.

strongly resistant to $\mathrm{SO}_{2}$ or $\mathrm{CO}_{2}$ poisoning. This is possibly because the introduction of a small amount of Pt prevents blocking of the active sites by adsorption of sulfur or carbon oxides. Corro et al. [55] reported that the presence of $\mathrm{Pt}^{0}$ might be necessary to prevent interactions between $\mathrm{SO}_{2}$ and Pd surface species. In the case of 3.0 vol\% water vapor addition, methane conversion over $1.41\left(\mathrm{Pd}_{5.1} \mathrm{Pt}\right) / \mathrm{meso}^{-} \mathrm{Mn}_{2} \mathrm{O}_{3}$ decreased by ca. $10 \%$, as a result of formation of hydroxyl groups on the support surface, which hindered oxygen exchange between the support and active sites [56]. It has been reported that $T_{50 \%}$ increased by ca. $100{ }^{\circ} \mathrm{C}$ over $\mathrm{Pd} / \mathrm{Al}_{2} \mathrm{O}_{3}$ in the presence of 10.0 vol\% water vapor [12], by ca. $35{ }^{\circ} \mathrm{C}$ over $\mathrm{PdO} / \mathrm{Al}_{2} \mathrm{O}_{3}$ in the presence of 3.0 vol\% water vapor [57], and by ca. $120{ }^{\circ} \mathrm{C}$ over $\mathrm{Pd} / \mathrm{ZrO}_{2}$, $\mathrm{Pd} / \mathrm{Zr}-\mathrm{CeO}_{2}$, and $\mathrm{Pd} / \mathrm{La}-\mathrm{CeO}_{2}$ in the presence of 18.0 vol\% water vapor [58]. The introduction of Pt therefore increased the resistance of the Pd-based catalysts to water vapor poisoning. An activity drop (ca. 30\%) was observed over $1.41\left(\mathrm{Pd}_{5.1} \mathrm{Pt}\right) / \mathrm{meso}^{-} \mathrm{Mn}_{2} \mathrm{O}_{3}$ in the presence of $1.0 \mathrm{vol} \% \mathrm{NO}$. The introduction of NO into the reaction system could interfere with methane combustion because of selective catalytic reduction of NO with methane, which could occur simultaneously with methane combustion [59]:

$$
\begin{aligned}
\mathrm{CH}_{4}+2 \mathrm{NO}+\mathrm{O}_{2} & \rightarrow \mathrm{CO}_{2}+2 \mathrm{H}_{2} \mathrm{O}+\mathrm{N}_{2} \\
\mathrm{CH}_{4}+2 \mathrm{O}_{2} & \rightarrow \mathrm{CO}_{2}+2 \mathrm{H}_{2} \mathrm{O}
\end{aligned}
$$

We used FT-IR spectroscopy to elucidate the surface species

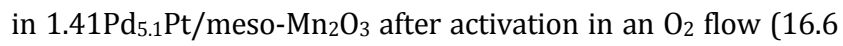
$\mathrm{mL} / \mathrm{min}$ ) at $250{ }^{\circ} \mathrm{C}$ for $1 \mathrm{~h}$ and after methane combustion in the presence of $100 \mathrm{ppm} \mathrm{SO}_{2}, 5.0$ vol\% $\mathrm{CO}_{2}, 3.0$ vol\% $\mathrm{H}_{2} \mathrm{O}$, and 1.0 vol\% NO; the spectra are shown in Fig. 12(b). According to the literature $[18,60,61]$, the absorption bands at 3400, 2360 and $2340,1625,1410$, and $930 \mathrm{~cm}^{-1}$ can be ascribed to the stretching vibrations of $\mathrm{OH}^{-}$, atmospheric $\mathrm{CO}_{2}$, bending vibrations of adsorbed water molecules, stretching vibrations of $\mathrm{C}-\mathrm{H}$ bonds, and stretching and bending vibrations of $\mathrm{Mn}-\mathrm{O}$ bonds, respectively. The absorption bands at 1125 and $1146 \mathrm{~cm}^{-1}$ [Fig. 12(b)(1)] can be assigned to oxygen species (e.g., $\mathrm{O}_{2}{ }^{-}$and $\mathrm{O}_{2}{ }^{2-}$ ) $[18,62]$. The absorption band at $1042 \mathrm{~cm}^{-1}$ indicates formation of $\mathrm{SO}_{3}{ }^{2-}$ or $\mathrm{SO}_{4}{ }^{2-}$ species [19]. No corresponding carbonate or $\mathrm{OH}^{-}$groups were detected (Fig. 12(b)(2) and (3)), possibly because of decomposition of carbonate or $\mathrm{OH}^{-}$species at high temperatures. The strong absorption band at $1140 \mathrm{~cm}^{-1}$ for the sample after methane combustion in the presence of $1.0 \mathrm{vol} \%$ NO can be assigned to NO adsorption on the support or noble-metal NPs [63]; this decreased the catalytic activity of the sample [59].

Fig. 13 shows TEM images of $1.41\left(\mathrm{Pd} \mathrm{P}_{5.1} \mathrm{Pt}\right) /$ meso- $\mathrm{Mn}_{2} \mathrm{O}_{3}$ after activation in $\mathrm{O}_{2}$ at $250{ }^{\circ} \mathrm{C}$ for $1 \mathrm{~h}$, after methane combustion in the presence of $100 \mathrm{ppm} \mathrm{SO}_{2}, 5.0 \mathrm{vol} \% \mathrm{CO}_{2}, 3.0 \mathrm{vol} \% \mathrm{CO}_{2}$, or 1.0 vol\% NO, and after $25 \mathrm{~h}$ of on-stream reaction. The images clearly show that all the samples maintained their high-quality mesoporous structure and the Pd-Pt alloy NPs were well distributed on the surface of the meso- $\mathrm{Mn}_{2} \mathrm{O}_{3}$ support (similar to the images in Fig. 2(g) and (h)).

\section{Conclusions}

We prepared meso- $\mathrm{Mn}_{2} \mathrm{O}_{3}$ and $x\left(\mathrm{Pd} \mathrm{d}_{y} \mathrm{Pt}\right) /$ meso- $^{-} \mathrm{Mn}_{2} \mathrm{O}_{3}$ nanocatalysts using KIT-6-templating and PVA-protected reduction methods, respectively. The porous samples had surface areas of 77-106 $\mathrm{m}^{2} / \mathrm{g}$ and noble-metal NPs of size 2-3 nm, and were highly dispersed on the surfaces of the cubic crystalline meso- $\mathrm{Mn}_{2} \mathrm{O}_{3}$ support. Alloying Pd with Pt enhanced the catalytic performance in methane combustion; $1.41\left(\mathrm{Pd}{ }_{5.1} \mathrm{Pt}\right) /$ meso- $\mathrm{Mn}_{2} \mathrm{O}_{3}$ showed the highest activity $\left(T_{10 \%}=\right.$ $265{ }^{\circ} \mathrm{C}, T_{50 \%}=345{ }^{\circ} \mathrm{C}$, and $T_{90 \%}=425{ }^{\circ} \mathrm{C}$ at $\mathrm{SV}=20000$ $\mathrm{mL} /(\mathrm{g} \cdot \mathrm{h}))$. Introduction of a small amount of Pt increased re- 

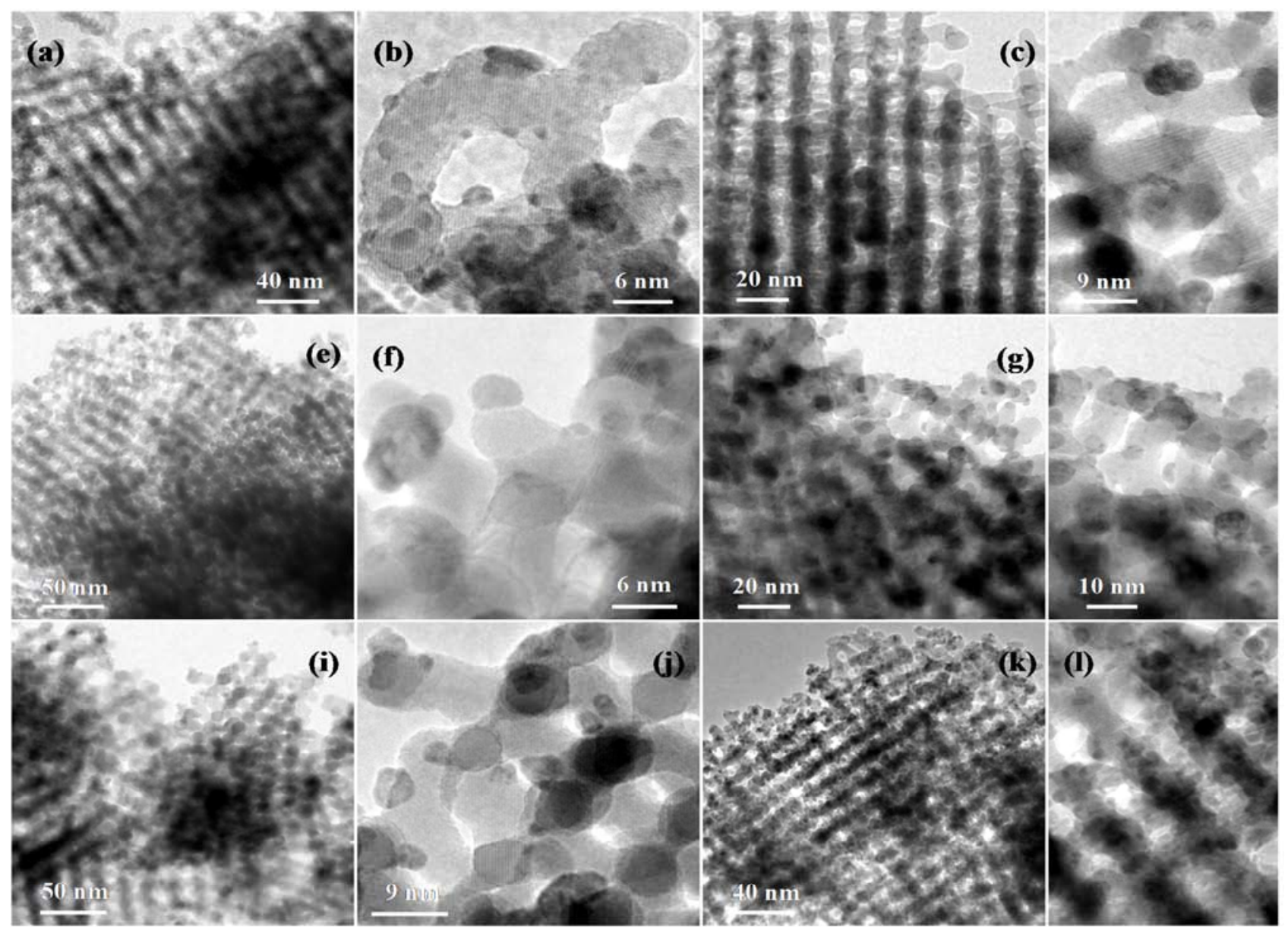

Fig. 13. TEM images of $1.41\left(\mathrm{Pd}_{5.1} \mathrm{Pt}\right) /$ meso- $\mathrm{Mn}_{2} \mathrm{O}_{3}(\mathrm{a}, \mathrm{b})$ after activation in $\mathrm{O}_{2}$ flow $(16.6 \mathrm{~mL} / \mathrm{min})$ at $250{ }^{\circ} \mathrm{C}$ for $1 \mathrm{~h}$; after methane combustion in the presence of (c, d) $100 \mathrm{ppm} \mathrm{SO}_{2}$, (e, f) 5.0 vol\% $\mathrm{CO}_{2}$, (g, h) 3.0 vol\% $\mathrm{H}_{2} \mathrm{O}$, or (i, j) 1.0 vol\% NO; and (k, l) after $25 \mathrm{~h}$ of on-stream reaction at $425{ }^{\circ} \mathrm{C}$ and SV $=20000 \mathrm{~mL} /(\mathrm{g} \cdot \mathrm{h})$.

sistance to $\mathrm{SO}_{2}, \mathrm{CO}_{2}$, and water vapor poisoning. However, $\mathrm{NO}$ addition negatively affected methane combustion because of selective catalytic reduction of NO with methane. It is concluded that a large surface area, high adsorbed oxygen species concentration, good low-temperature reducibility, and strong interactions between the Pd-Pt alloy NPs and meso- $\mathrm{Mn}_{2} \mathrm{O}_{3}$ were responsible for the excellent catalytic performance of 1.41( $\left.\mathrm{Pd}_{5.1} \mathrm{Pt}\right) /$ meso- $\mathrm{Mn}_{2} \mathrm{O}_{3}$.

\section{References}

[1] M. N. Debbagh, C. S. M. de Lecea, J. Pérez-Ramírez, Appl. Catal. B, 2007, 70, 335-341.

[2] Z. Q. Yang, J. R. Grace, C. J. Lim, L. Zhang, Energy Fuels, 2011, 25, 975-980.

[3] L. A. Graham, G. Rideout, D. Rosenblatt, J. Hendren, Atmos. Environ., 2008, 42, 4665-4681.

[4] P. Gélin, M. Primet, Appl. Catal. B, 2002, 39, 1-37.

[5] D. Ciuparu, M. R. Lyubovsky, E. Altman, L. D. Pfefferle, A. Datye, Catal. Rev. Sci. Eng., 2002, 44, 593-649.

[6] J. Xu, L. K. Ouyang, W. Mao, X. J. Yang, X. C. Xu, J. J. Su, T. Z. Zhuang, H. Li, Y. F. Han, ACS Catal., 2012, 2, 261-269.

[7] J. D. Grunwaldt, N. van Vegten, A. Baiker, Chem. Commun., 2007, 44, 4635-4637.

[8] A. Hellman, A. Resta, N. M. Martin, J. Gustafson, A. Trinchero, P. A.
Carlsson, O. Balmes, R. R. Felici, R. van Rijn, J. W. M. Frenken, J. N. Andersen, E. Lundgren, H. Grönbeck, J. Phys. Chem. Lett., 2012, 3, 678-682.

[9] A. Ersson, H. Kusar, R. Carroni, T. Griffin, S. Järås, Catal. Today, 2003, 83, 265-277.

[10] K. Persson, A. Ersson, K. Jansson, N. Iverlund, S. Järås, J. Catal,, 2005, 231, 139-150.

[11] T. V. Choudhary, S. Banerjee, V. R. Choudhary, Appl. Catal. A, 2002, 234, 1-23.

[12] P. Gélin, L. Urfels, M. Primet, E. Tena, Catal. Today, 2003, 83, 45-57.

[13] N. M. Kinnunen, J. T. Hirvi, M. Suvanto, T. A. Pakkanen, J. Mol. Catal. A, 2012, 356, 20-28.

[14] H. Yoshida, T. Nakajima, Y. Yazawa, T. Hattori, Appl. Catal. B, 2007, 71, 70-79.

[15] A. Barrera, S. Fuentes, G. Diaz, A. Gomez-Cortes, F. Tzompantzi, J.C. Molina, Fuel, 2012, 93, 136-141.

[16] K. Ramesh, E. Widjaja, S. Chilukoti, I. K. Surjami, J. S. Chen, J. Catal., 2008, 253, 261-268.

[17] K. Ramesh, L. W. Chen, F. X. Chen, Z. Y. Zhong, J. H. Chin, H. W. Mook, Y. F. Han, Catal. Commun., 2007, 8, 1421-1426.

[18] J. H. Li, X. Liang, S. C. Xu, J. M. Hao, Appl. Catal. B, 2009, 90, 307-312.

[19] S. Ordóñez, J. R. Paredes, F. V. Díez, Appl. Catal. A, 2008, 341, 174-180.

[20] M. R. Morales, B. P. Barbero, L. E. Cadús, Appl. Catal. B, 2006, 67, 
229-236.

[21] A. Machocki, T. Ioannides, B. Stasinska, W. Gac, G. Avgouropoulos, D. Delimaris, W. Grzegorczyk, S. Pasieczna, J. Catal., 2004, 227, 282-296.

[22] Z. X. Wu, J. G. Deng, Y. X. Liu, S. H. Xie, Y. Jiang, X. T. Zhao, J. Yang, H. Arandiyan, G.S. Guo, H.X. Dai, J. Catal., 2015, 332, 13-24.

[23] S. H. Xie, J. G. Deng, S. M. Zang, H. G. Yang, G. S. Guo, H. Arandiyan, H. X. Dai, J. Catal., 2015, 322, 38-48.

[24] S. H. Xie, J. G. Deng, Y. X. Liu, Z. H. Zhang, H. G. Yang, Y. Jiang, H. Arandiyan, H. X. Dai, C. T. Au, Appl. Catal. A, 2015, 507, 82-90.

[25] S. H. Xie, H. X. Dai, J. G. Deng, H. G. Yang, W. Han, H. Arandiyan, G. S. Guo, J. Hazard. Mater., 2014, 279, 392-401.

[26] Y. X. Liu, H. X. Dai, J. G. Deng, S. H. Xie, H. G. Yang, W. Tan, W. Han, Y. Jiang, G. S. Guo, J. Catal., 2014, 309, 408-418.

[27] Z. X. Wu, J. G. Deng, S. H. Xie, H. G. Yang, X. T. Zhao, K. F. Zhang, H. X. Lin, H. X. Dai, G. S. Guo, Microporous Mesoporous Mater., 2016, 224, 311-322.

[28] J. G. Deng, S. N. He, S. H. Xie, H. G. Yang, Y. X. Liu, G. S. Guo, H. X. Dai, Environ. Sci. Technol., 2015, 49, 11089-11095.

[29] F. Kleitz, S. H. Choi, R. Ryoo, Chem. Commun., 2003, 2136-2137.

[30] X. H. Sun, Y. F. Shi, P. Zhang, C. M. Zheng, X. Y. Zheng, F. Zhang, Y. C. Zhang, N. J. Guan, D. Y. Zhao, G. D. Stucky, J. Am. Chem. Soc., 2011, 133, 14542-14545.

[31] S. H. Xie, J. G. Deng, S. M. Zang, H. G. Yang, G. S. Guo, H. Arandiyan, H. X. Dai, J. Catal., 2015, 322, 38-48.

[32] V. P. Santos, M. F. R. Pereira, J. J. M. Órfão, J. L. Figueiredo, Appl. Catal. B, 2010, 99, 353-363.

[33] Y. J. Wei, L. Y. Yan, C. Z. Wang, X. G. Xu, F. Wu, G. Chen, J. Phys. Chem. $B, \mathbf{2 0 0 4}, 108,18547-18551$.

[34] K. Jiratova, J. Mikulova, J. Klempa, T. Grygar, Z. Bastl, F. Kovanda, Appl. Catal. A, 2009, 361, 106-116.

[35] H. Q. Dong, Y. Y. Chen, M. Han, S. L. Li, J. Zhang, J. S. Li, Y. Q. Lan, Z. H. Dai, J. C. Bao, J. Mater. Chem. A, 2014, 2, 1272-1276.

[36] Y. B. He, G. R. Li, Z. L. Wang, Y. N. Ou, Y. X. Tong, J. Phys. Chem. C, 2010, 114, 19175-19181.

[37] J. Prabhuram, T. S. Zhao, C. W. Wong, J. W. Guo, J. Power Sources, 2004, 134, 1-6.

[38] B. Solsona, T. García, S.H. Taylor, G.J. Hutchings, M. Makkee, Appl. Catal. A, 2009, 365, 222-230.

[39] H. J. Wu, L. D. Wang, J. Q. Zhang, Z. Y. Shen, J. H. Zhao, Catal. Commun., 2011, 12, 859-865.

[40] D. S. Zhang, L. Zhang, C. Fang, R. H. Gao, Y. L. Qian, L. Y. Shi, J. P. Zhang, RSC Adv., 2013, 3, 8811-8819.
[41] Y. X. Liu, H. X. Dai, Y. C. Du, J. G. Deng, L. Zhang, Z. X. Zhao, C. T. Au, J. Catal., 2012, 287, 149-160.

[42] W. Gac, Appl. Catal. B, 2007, 75, 107-117.

[43] R. Xu, X. Wang, D. S. Wang, K. B. Zhou, Y. D. Li, J. Catal., 2006, 237, 426-430.

[44] S. Rousseau, S. Loridant, P. Delichere, A. Boreave, J.P. Deloume, P. Vernoux, Appl. Catal. B, 2009, 88, 438-447.

[45] D. I. Enache, J. K. Edwards, P. Landon, B. Solsona-Espriu, A. F. Carley, A. A. Herzing, M. Watanabe, C. J. Kiely, D. W. Knight, G. J. Hutchings, Science, 2006, 311, 362-365.

[46] D. S. Lee, Y. W. Chen, J. Taiwan Inst. Chem. Eng., 2013, 44, 40-44.

[47] J. N. Carstens, S. C. Su, A. T. Bell, J. Catal., 1998, 176, 136-142.

[48] K. Persson, A. Ersson, K. Jansson, J. L. G. Fierro, S. G. Järås, J. Catal., 2006, 243, 14-24.

[49] F. Teng, W. Qu, G. D. Wen, Z. M. Wang, Z. J. Tian, X. M. Yang, P. Xu, Y. F. Zhu, G. X. Xiong, Microporous Mesoporous Mater., 2008, 111, 620-626.

[50] W. R. Schwartz, D. Ciuparu, L. D. Pfefferle, J. Phys. Chem. C, 2012, 116, 8587-8593.

[51] P. Hurtado, S. Ordóñez, H. Sastre, F.V. Dìez, Appl. Catal. B, 2004, 51, 229-238.

[52] S. Ordóñez, L. Bello, H. Sastre, R. Rosal, F.V. Dìez, Appl. Catal. B, 2002, 38, 139-149.

[53] L. Ren, P. P. Wang, Y. S. Han, C. W. Hu, B. Q. Wei, Chem. Phys. Lett., 2009, 476, 78-83.

[54] K. Sasaki, O. Tanaike, H. Konno, Can. Mineral., 1998, 36, 1225-1235.

[55] G. Corro, C. Cano, J. L. G. Fierro, J. Mol. Catal. A, 2010, 315, 35-42.

[56] A. T. Gremminger, H. W. P. de Carvalho, R. Popescu, J. D. Grunwaldt, O. Deutschmann, Catal. Today, 2015, 258, 470-480.

[57] D. Ciuparu, E. Perkins, L. Pfefferle, Appl. Catal. A, 2004, 263, 145-153.

[58] S. Eriksson, M. Boutonnet, S. Järås, Appl. Catal. A, 2006, 312, 95-101.

[59] Y. H. Chin, D. E. Resasco, Catalysis, 1999, 14, 1-39.

[60] S. M. Li, Y. L. Wang, M. G. Ma, J. F. Zhu, R. C. Sun, F. Xu, Crop. Prod., 2013, 43, 751-756.

[61] X. Y. Wang, L. Liu, X. Y. Wang., L. H. Yi, C. Y. Hu, X. Y. Zhang, Mater. Sci. Eng. B, 2011, 176, 1232-1238.

[62] Z. H. Li, G. H. Xu, G. B. Hoflund, Fuel Process. Technol., 2003, 84, 1-11.

[63] A. Martinez-Arias, J. Soria, J. C. Conesda, X. L. Seoane, A. Arcoya, R. Cataluna, J. Chem. Soc. Faraday Trans., 1995, 91, 1679-1687.

\section{Graphical Abstract}

Chin. J. Catal., 2017, 38: 92-105 doi: 10.1016/S1872-2067(16)62567-6

Catalytic performance enhancement by alloying Pd with Pt on ordered mesoporous manganese oxide for methane combustion

Peng Xu, Zhixing Wu, Jiguang Deng, Yuxi Liu, Shaohua Xie, Guangsheng Guo*, Hongxing Dai*

Beijing University of Technology

Alloying Pd with Pt enhanced the catalytic performance in methane combustion. 1.41 $\left(\mathrm{Pd}_{5.1} \mathrm{Pt}\right) /$ meso- $\mathrm{Mn}_{2} \mathrm{O}_{3}$ showed the highest activity because of its large surface area, high $\mathrm{O}_{\text {ads }}$ concentration, good low-temperature reducibility, and strong Pd-Pt alloy and $\mathrm{Mn}_{2} \mathrm{O}_{3}$ interactions.

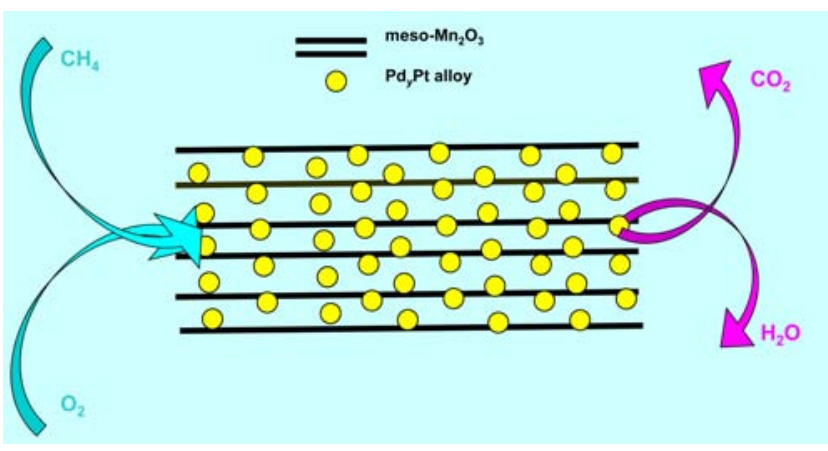




\title{
有序介孔三氧化二锰负载PdPt合金: 一种高效的甲烷催化燃烧催化剂
}

\author{
徐 鹏, 吴志星, 邓积光, 刘雨溪, 谢少华, 郭广生 ${ }^{*}$, 戴洪兴 ${ }^{\#}$ \\ 绿色催化与分离北京市重点实验室, 区域大气复合污染防治北京市重点实验室, 先进功能材料教育部重点实验室, 催化化学与纳 \\ 米科学实验室, 北京工业大学环境与能源工程学院化学化工系, 北京100124
}

摘要: 甲烷作为一种清洁廉价的碳氢能源, 广泛应用于运输业和其它工业领域. 但是其本身是一种比二氧化碳导致全球变 暖效应更强的温室气体, 而且甲烷直接燃烧会产生其它污染物, 比如一氧化碳、氮氧化物、未充分燃烧的碳氢化合物等. 因 此有必要开展有关甲烷催化燃烧的研究工作, 以大幅度降低起燃温度, 提高燃烧效率, 有效地减少污染副产物的产生. 由 于具有较好的低温催化活性, Pd基催化剂常用于甲烷的催化燃烧. 但是Pd基催化剂也存在一些亟需解决的问题, 比如在催 化燃烧过程中活性相结构不稳定. $\mathrm{PdO}$ 通常被认为是碳氢化合物催化氧化中的活性相, 但是在高温下 PdO分解为 Pd, 导致 催化活性下降. PdO遇到含水或硫的化合物时会生成惰性的 $\mathrm{Pd}(\mathrm{OH})_{2}$ 或稳定的硫化物, 造成活性物种的流失, 从而降低催化 剂的性能. 如果在材料中添加另一种贵金属 $\mathrm{Pt}$, 使之与Pd一起形成贵金属合金, 则可提高其低温催化燃烧的活性, 增加Pd基 催化剂的热稳定性以及抗水和抗硫能力. 另一方面, 过渡金属氧化物价格便宜, 热稳定性以及抗硫性较好, 也常作为甲烷 燃烧的催化剂. 其中三氧化二锰由于具有可变的氧化态以及较好的储氧能力受到了广泛关注. 本课题组采用KIT-6作为硬 模板, 先合成具有有序介孔结构的 $\mathrm{Mn}_{2} \mathrm{O}_{3}$ (meso- $\mathrm{Mn}_{2} \mathrm{O}_{3}$ ) 纳米催化剂, 然后通过聚乙烯醇(PVA)保护的液相共还原法分别制 备meso- $\mathrm{Mn}_{2} \mathrm{O}_{3}$ 担载Pd, Pt及PdPt合金的纳米催化剂 $\left(x\left(\mathrm{Pd}_{y} \mathrm{Pt}\right) / \mathrm{meso}^{-} \mathrm{Mn}_{2} \mathrm{O}_{3} ; x=(0.10-1.50) \mathrm{wt} \% ; \mathrm{Pd} / \mathrm{Pt}\right.$ 摩尔比 $\left.(y)=4.9-5.1\right)$.

$\mathrm{XRD}$ 结果表明, 合成的 meso- $\mathrm{Mn}_{2} \mathrm{O}_{3}$ 具有立方相晶体结构. 其BET比表面积为 $106 \mathrm{~m}^{2} / \mathrm{g}$. 由 TEM照片可观察到粒径范围 为2.1-2.8 nm的贵金属纳米颗粒均匀分散在 meso- $\mathrm{Mn}_{2} \mathrm{O}_{3}$ 表面. 通过XPS分析可知, 结合能在 529.6 和 $531.2 \mathrm{eV}$ 的峰可分别归 属于晶格氧 $\left(\mathrm{O}_{\text {latt }}\right)$ 和表面吸附氧 $\left(\mathrm{O}_{\mathrm{ads}}\right) . \mathrm{Pd}^{0}$ 和 $\mathrm{Pd}^{2+}$ 以及 $\mathrm{Pt}^{0}$ 和 $\mathrm{Pt}^{2+}$ 也均可通过曲线拟合后进行分峰确定. $\mathrm{XPS}$ 定量分析结果表 明, 样品的 $\mathrm{O}_{\text {ads }} / \mathrm{O}_{\text {latt }}$ 摩尔比有如下顺序: 1.41 $\left(\mathrm{Pd}_{5.1} \mathrm{Pt}\right) / \mathrm{meso}^{-\mathrm{Mn}_{2} \mathrm{O}_{3}}(0.77)>1.40 \mathrm{Pd} / \mathrm{meso}-\mathrm{Mn}_{2} \mathrm{O}_{3} \quad(0.69)>$

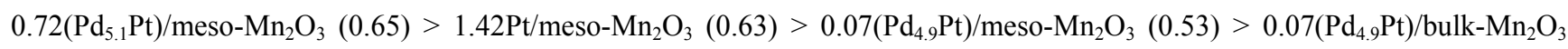
$(0.52)>$ meso- $\mathrm{Mn}_{2} \mathrm{O}_{3}(0.45)$, 这与其催化活性的顺序一相致. 该结果表明, 高的吸附氧物种浓度有利于甲烷催化燃烧. 负载 $\mathrm{Pd}$, Pt或PdPt以后的样品的表面吸附氧物种浓度显著提高, 催化活性最好的 $1.41\left(\mathrm{Pd}_{5.1} \mathrm{Pt}\right) / \mathrm{meso}^{-} \mathrm{Mn}_{2} \mathrm{O}_{3}$ 样品具有最高的吸附 氧物种浓度.

负载PdPt合金可有效提高催化剂对甲烷燃烧的催化活性. $1.41\left(\mathrm{Pd}_{5.1} \mathrm{Pt}\right) / \mathrm{meso}^{-} \mathrm{Mn}_{2} \mathrm{O}_{3}$ 催化剂的活性最好: 在空速为 $20000 \mathrm{~mL} /(\mathrm{g} \cdot \mathrm{h})$ 的条件下, 甲烷燃烧的 $T_{10 \%}, T_{50 \%}$ 和 $T_{90 \%}$ 分别为 265,345 和 $425^{\circ} \mathrm{C}$. 此外, 还考察了引入一定量的 $\mathrm{SO}_{2}, \mathrm{CO}_{2}, \mathrm{H}_{2} \mathrm{O}$ 和 NO对甲烷在 $1.41\left(\mathrm{Pd}_{5.1} \mathrm{Pt}\right) /$ meso- $\mathrm{Mn}_{2} \mathrm{O}_{3}$ 催化剂上氧化反应的影响, 发现引入少量的Pt可提高催化剂抗 $\mathrm{SO}_{2}, \mathrm{CO}_{2}$ 和 $\mathrm{H}_{2} \mathrm{O}$ 的能 力, 但是 $\mathrm{NO}$ 对甲烷燃烧的还原效应也不可忽视. 基于催化剂物化性质的表征结果和活性数据, 我们认为 1.41 $\left(\mathrm{Pd}_{5.1} \mathrm{Pt}\right) / \mathrm{meso}^{-} \mathrm{Mn}_{2} \mathrm{O}_{3}$ 优异的催化性能与其拥有高质量的三维有序多孔结构、高的吸附氧物种浓度、优良的低温还原性 以及Pd-Pt合金与meso- $\mathrm{Mn}_{2} \mathrm{O}_{3}$ 载体之间的强相互作用有关.

关键词: 有序介孔三氧化二锰; PdPt合金纳米颗粒; 负载贵金属催化剂; 金属-载体强相互作用; 甲烷燃烧

收稿日期: 2016-08-31. 接受日期: 2016-09-25. 出版日期: 2017-01-05.

*通讯联系人. 电话: (010)67396118; 传真: (010)67391983, 电子信箱: guogs@bjut.edu.cn

通讯联系人. 电话: (010)67396118; 传真: (010)67391983, 电子信箱: hxdai@bjut.edu.cn

基金来源：教育部博士点项目基金(20131103110002); 国家自然科学基金(21377008); 国家高技术研究发展计划(863计划; 2015AA034603); 北京市高校创新团队建设推进计划基金; 科学研究基地建设一科技创新平台一国家材料研究基地建设基金. 本文的英文电子版由Elsevier出版社在ScienceDirect上出版(http://www.sciencedirect.com/science/journal/18722067). 